\title{
ばね及びばね鋼のX線残留応力測定法*
}

\author{
X線によるばねの残留応力評価法研究委員会
}

\section{Method for X-ray Residual Stress Analysis in Springs and Spring Steel}

\author{
Research Committee for Evaluation in Residual Stress of Spring by X-ray Diffraction
}

\begin{tabular}{|c|c|c|c|c|c|c|}
\hline \multirow{3}{*}{$\begin{array}{l}\text { 委員 長 } \\
\text { 副委員長 }\end{array}$} & \multicolumn{6}{|c|}{ 「X線によるばねの残留応力評価法研究委員会」 } \\
\hline & 大谷 眞一 & 東京都市大学工学部 & 委 & 武田 & 和孝 & 村田発條(侏) \\
\hline & 小木曽克彦 & (株)ジャクセル & " & 中島 & 俊司 & 日本発条(株) \\
\hline " & 余語 英俊 & 愛知製鋼侏) & " & 西島 & 敏 & 日本ばね学会名誉会長 \\
\hline " & 三村 真吾 & 中央発條侏) & " & 横山 & 亮一 & (侏)リガク \\
\hline " & 後藤由利香 & 日本発条(侏) & " & 松本 & 彰久 & 愛知製鋼(株) \\
\hline 員 & 伊澤＼cjkstart佳伸 & (株)東郷製作所 & " & 服部 & 兼久 & 東洋精鋼(侏) \\
\hline " & 川口 & 鈴木金属工業(侏) & " & 根津 & 暁充 & (株りリガク \\
\hline " & 小林 祐次 & 新東工業(侏) & " & 竹田 & 和也 & 東京都市大学（院） \\
\hline " & 重松 正明 & 知多鋼業(侏) & & & & \\
\hline
\end{tabular}

X-ray stress measurement is a technique which has been widely applied to residual stress. However, a satisfactory method for measuring residual stress in springs has not been appropriately developed yet. Thus, a research committee in Japan Society of Spring Engineers was established to research the X-ray based stress measurement of springs in 2008. The first item accomplished by the committee was an exploratory investigation to understand the measuring conditions of X-ray stress measurement being used in spring industries. By referring to these results obtained, four subjects were investigated as follows: a) development of a method of residual stress measurement in shot-peened plate, b) development of a method of residual stress measurement in shot-peened round-bar, c) evaluation method for $2 \theta-\sin ^{2} \psi$ diagrams, d) characterization of an X-ray stress constant in ferrous spring steels.

The following results were obtained:

(1) The errors for $68.3 \%$ confidence limits in the residual stress of the shot-peened plate specimen, which were observed by X-ray stress measurement under routine measurement conditions in participating companies, were within $6 \%$ of the average residual stress values obtained. Therefore, X-ray stress measurement conditions based on a $68.3 \%$ confidence limit were proposed.

(2) In a sample with a curved surface, such as a coil spring, the diameter of an X-ray collimator should be less than $20 \%$ of the diameter of the spring wire so that the error of the residual stress can be less than $10 \%$. It turned out that the nonlinearity of the $2 \theta-\sin ^{2} \psi$ diagrams and wave-like fluctuation in diffraction intensity$\sin ^{2} \psi$ diagrams were observed in the surface of fine-shot-peened round-bars.

(3) An evaluation method for $2 \theta-\sin ^{2} \psi$ diagrams showing the pattern of bowing or waving using two statistical approaches and simulations in tri-axial stress states has been investigated. Two parameters $\mathrm{C}_{\mathrm{B}}$ and $\mathrm{C}_{\mathrm{w}}$ representing degrees of the bowing and waving in $2 \theta-\sin ^{2} \psi$ diagrams have been suggested. At least seven diffraction angles in the $2 \theta-\sin ^{2} \psi$ diagram are necessary to evaluate waving. A simulation of the $2 \theta-\sin ^{2} \psi$ diagram enables us to confirm effectiveness of the evaluation technique with $\mathrm{C}_{\mathrm{B}}$ and $\mathrm{C}_{\mathrm{w}}$.

(4) A round robin test (RRT) for characterization of an X-ray stress constant in ferrous spring steels such as SUP9A and SUP12 was carried out. As a result, it appears that the average X-ray stress constant K in the two spring steels was $-338 \pm 13.1 \mathrm{MPa} / \mathrm{deg}$.

Key Words : X-ray stress measurement, Residual stress, Shot peening, X-ray stress constant, $2 \theta-\sin ^{2} \psi$ diagram, Ferrous spring steel 


\section{1. 緒言}

ばねはショットピーニングにより発生する圧縮残留応力 で耐久限度向上が図られている. ISO規格策定におけるショ ットピーニングの技術分野TC227「ばね」では，ショットピ ーニング処理はばねには必要不可欠で重要であるという認 識で一致している.

ばねの残留応力の測定方法として，おもなばね関連企業 ではX線応力測定法を採用している。しかし，X線応力測定 の原理に関して理解はされているものの, X線入射角の範囲 や入射角点数, X線応力定数, X線光学系の差違などいわゆ る測定条件の選択，あるいは被測定物における結晶の粒 度・配向度合，ショットピーニングによる表面粗さや表面 形状（コイルばねや弁ばねのように測定表面が平面でない ような場合), 測定物の加工履歴などの影響により残留応力 の絶対值が異なることがあり, X線応力測定法の信頼度まで 議論に至る場合もある。

X線を用いた残留応力の測定方法については, 日本材料 学会が $2 \theta-\sin ^{2} \psi$ 法に基づく「X線応力測定法標準 $\rfloor^{1)}$ を制 定・改定刊行しているほか，ショットピーニングのJISB2711の付属書「残留応力の測定方法 $\left.{ }^{2}\right) に も$ 示されている. しかし，X線応力測定法標準では，測定表面が曲面であるこ とはほとんど想定しておらず，また推奨しているフェライ 卜系鉄鋼材のX線応力定数 $(-318 \mathrm{MPa} / \mathrm{deg})$ は種々のフェ ライト系鉄鋼の平均值である. JIS-B2711の付属書に関して もショットピーニング処理後の残留応力をX線応力測定で求 めるための汎用規定であり, 例えばX線応力測定の際の $\sin ^{2} \psi$ 範囲やX線入射角点数などの測定条件は，「X線応力測 定法標準」の条件とも異なっている。いずれにしても，現在 ばね及びばね鋼固有のX線応力測定法指針を示しているもの は存在しない.

このような現状を基に，2008年度に日本ばね工業会から 日本ばね学会に「ショットピーニング処理されたばねに限定 したX線応力測定法の標準化を目標とした研究を行う」う 要請があり，「X線によるばねの残留応力評価法研究委員会」 が発足した。本研究委員会は2008年7月から2011年3月まで 計16回に亘り委員会を開催した。構成委員は上揭のと打り である。

本研究委員会は，まずばね関連企業でのX線応力測定の 使用実態調査（アンケート）を行い，その結果から委員会 が取扱うテーマを決定した。

そして，(1)ショットピーニング処理したばね鋼平板の残 留応力測定 (第1回ラウンドロビン試験，以後RRTと呼ぶ), (2)ショットピーニング処理した丸棒の残留応力測定（第2回 RRT), (3) $2 \theta-\sin ^{2} \psi$ 線図の評価法, (4)フェライト系ばね鋼の X線応力定数の測定（第3回RRT）の4項目について研究活動 を行ってきた。

本報告はそれぞれの項目に関して，委員会活動で得られ た成果について総括する.

\section{X線応力測定の使用実態調査}

ばね関連企業でのX線応力測定法の使用実態のアンケー 卜調査を行い，測定条件設定などの情報収集を行った．

アンケートの大きな項目は以下の 4 点である. (1)測定試料 と表面処理方法, (2)使用しているX線応力測定装置, (3)応力 測定条件，(4)応力值の算出 である.

アンケートはばねメーカー, 材料メーカー, カーメーカ 一などを対象に157機関に依頼し，37機関から回答を得た ${ }^{3)}$. 以下，おもな結果を示す。

\section{1 測定試料と処理方法}

おもな測定試料の回答結果をFig. 1に示す．測定試料は板 ばねと一部の素材を除けばコイル状・小物の測定物が多く, 応力測定の困難さが想像される.

酸化スケール，塗装膜の除去方法については70\%以上の 機関がエメリー紙などによる研磨, 剥離剂, 酸洗, 電解研 磨など何らかの方法により除去している。

また，ばねにとってはショットピーニング処理の加工条 件評価には残留応力の深さ分布が欠かせない．深さ方向の 応力分布を測定する際の表面除去領域と除去方法は，部分 除去している機関が70\%，表面を全面除去している機関が $30 \%$ であ，除去方法は電解研磨が $68 \%$ ，化学腐食が $26 \%$ であった，使用する電解液，腐食液は各所で様々なものが 使用されている.

\subsection{X線応力測定装置}

アンケート回答数は37機関であるが，これらの機関はX線 応力測定装置を複数所有している. 回答者の所有X線応力測 定装置は総数53台であったが，その内国内メーカー製装置 が $87 \%$ と多い。ただし外国製や自作の装置を使用している 機関もある。装置のX線検出器は位置敏感型比例計数管 (PSPC) 58\%，シンチレーション計数管（SC）38\%である. その他は主に外国製の装置に装着されているPSD（位置敏 感型検出器）である。

\section{3 応力測定条件}

まず回答機関 37 のち $80 \%$ の機関が $2 \theta-\sin ^{2} \psi$ 法（以後

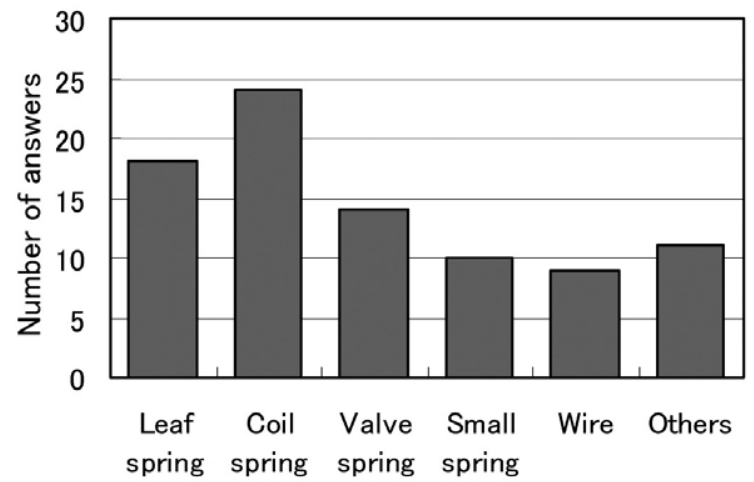

Fig. 1 Answer of question for "What kind of spring or products do you usually measure by the X-ray stress analysis?" (Possible for multiple answers) 
$\sin ^{2} \psi$ 法と略す）を用いている。 それ以外は測定時間短縮の ために0-45 法, 装置付属のソフトに依存して $\sin ^{2} \psi$ 法以外 の方法も使用されている.

回折強度曲線の測定方式の質問には $87 \%$ の機関が並傾法 で測定している。回折強度曲線測定の光学系は, 検出器に PSPCの使用が多いため $\psi_{0}$ 一定法が $65 \%$ で， ている機関も20\%ある。また，摇動法を併用している機関 も18\%ある。

また照射面積の制限については，制限を実施している機 関と実施していない機関の数は半々であり, 制限の方法と してはビニルテープによるマスキングが多い.

X線照射スリット，受光側スリットの種類はPSPCの使用 が多いため，X線照射スリットはコリメータが76\%である。 同様の理由で受光側スリットは使用していない機関が多い が，ソーラスリットを使用している機関も30\%ある。

X線入射角の設定方法については $\sin ^{2} \psi$ 值を等間隔にして いる機関と㘯角または角を等間隔にしている機関が同数程 度ある。なお $\sin ^{2} \psi$ 值を等間隔にしている機関では最大 $\sin ^{2} \psi$ 值を $0.5 〜 0.7$, 点数を $4 \sim 7$ 点としている機関が大半を占める. 一方，40角または悀を等間隔としている場合は最大值を 40 $\sim 45^{\circ}$, 点数を $4 \sim 7$ 点としている機関が大半を占める. なお, ここで $0_{0}$ 角は試料法線と入射X線のなす角で正確な意味のX 線入射角である。一方，悀は試料法線と回折面法線のなす 角であるが，以後，本論文中では角を広義の意味で “X線 入射角”と記述する。

また回折強度曲線のピーク計数值に関しては約70\%の機 関で500〜2000カウントで測定している.

\section{4 応力値の算出}

応力算出手順にしたがって結果を概説する。バックグラ ウンド補正に関しては，90\%の機関が直線回帰して回折強 度曲線から削除している。回折強度曲線の補正は，72\%の 機関がLPA補正を実施している。回折強度曲線のスムージ ングは $80 \%$ の機関が重み付き移動平均法を実施している。 平均化点数は 5〜 7点で実施している機関が多い. ピーク位 置決定法は半価幅中点法で行っている機関が $82 \%$ あるる.

フェライト系ばね鋼の場合, 使用しているX線応力定数 $K$ は日本材料学会「X線応力測定法標準」 ${ }^{1)}$ の $K$ 值 $=$ $-318 \mathrm{MPa} / \mathrm{deg}$ を使っている機関が72\%であり，その他は外 部付加応力実験による実験值，あるいは機械的なヤング率 $E$ とポアソン比レ, 無ひずみ時の回折角 $2 \theta_{0}$ から後述の式 （25）を用いて算出した值を使っている機関もある.

深さ方向の残留応力分布を測定する際の表面除去に伴う 応力值補正に関しては $80 \%$ の機関は行っていない.

\section{5 アンケート結果からの検討課題}

本アンケート調査では特に応力測定条件，応力值の算出 方法について機関ごとに任意の方法で実施しており統一性 がなかった。ばねの残留応力測定の標準化を進めるには 様々な項目について測定值への影響を調査し，適切な方法， 条件を検討していくことが必要であることがわかった。

そこで本委員会では次の $4 つ の$ 課題を重点的に「標準的な 測定法」の提案のための研究を実施することとした。

(1) 各機関が日常的に行っている測定条件下での応力值の ばらつきの把握と，測定誤差を小さくするための基本的 な測定条件の検討

（2）コイルばねや弁ばねなどの測定面が曲率を有する試料 を測定する際の測定值に影響を与える因子と推奨測定条 件の検討

(3) 回折角 $2 \theta-\sin ^{2} \psi$ 線図（以後, 特に断らない限り $\sin ^{2} \psi$ 線 図と略す.）における非直線度の評価方法の検討

(4) フェライト系ばね鋼X線応力定数の提案

\section{3. ショットピーニング処理した平板の残留応力測定}

2章のアンケート結果を精査し, 各機関の応力測定条件が 大きく異なっていたことから，まず各機関がそれぞれ日常 業務で行っている条件で測定した残留応力值のばらつきを 確認するために，ラウンドロビン試験（RRT）を行った.

\section{1 試験片及び応力測定方法}

試験片としては，無ひずみ状態と見込まれる鉄粉末（以 後Fe粉末と呼ぶ）とショットピーニング平板試験片（以後 $\mathrm{SP}$ 試験片と呼ぶ）を使用した。

$\mathrm{SP}$ 試験片の供試材はSUP9で，試験片寸法を幅 $70 \mathrm{~mm} \times$ 長 さ $100 \mathrm{~mm} \times$ 板厚 $10 \mathrm{~mm}$ に機械加工し，表面を研削加工した 後ショットピーニングを行った。 ショットピーニング条件 をTable 1に示す.

$\mathrm{SP}$ 試験片は加工条件をすべて同一にしたものを3個用意 した。同時に無ひずみ状態を想定したFe粉末も3個準備した。 ラウンドロビン試験の参加機関は18機関，22装置であり， 参加機関を3系統に分けて SP試験片，Fe粉末試験片各 1 個ず つを測定した。

X線応力測定は特性X線 $\mathrm{Cr} \mathrm{K} \alpha$ 線で $\alpha \mathrm{Fe} 211$ 回折を測定, $\mathrm{X}$ 線応力定数は- $318 \mathrm{MPa} / \mathrm{deg}$ で固定, その他の条件は任意と した。また，Fe粉末は測定方向を指定せず3回反復測定， $\mathrm{SP}$ 試験片については試験片長手方向 $(x$ 方向 $)$, 幅方向 $y$ 方 向）の2方向をそれぞれ3回反復測定した。なお測定位置は 試験片中央部とした。

Table 1 Material used and shot peening conditions of specimen.

\begin{tabular}{|c|c|c|c|c|c|}
\hline \multicolumn{2}{|c|}{ Specimen } & \multicolumn{4}{c|}{ Peening conditions } \\
\hline Material & Surface hardness & Shot media & Speed & Arc height & Coverage \\
\hline SUP9 & HV 430 & $\begin{array}{c}\text { RCW06PM } \\
(\phi 0.6 \mathrm{HV} 450 \sim 550)\end{array}$ & $73 \mathrm{~m} / \mathrm{s}$ & $0.352 \mathrm{mmA}$ & $200 \%$ \\
\hline
\end{tabular}




\section{2 測定結果}

RRT結果をFig. 2に示す。図中のエラーバーは， $\sin ^{2} \psi$ 線図 の標準誤差 $\Delta M$ から求めた応力の $68.3 \%$ 信頼限界値 $\Delta \sigma$ (以後 測定誤差と呼ぶ）である．Fe粉末の結果において，1機関だ け他と大きく異なる結果 $(-80 \sim-110 \mathrm{MPa})$ となっている が，これは装置校正の不備によるものと判明したため, 以 降の解析ではこの装置のデー夕は除外している（なお，校 正後の再測定では他装置と同等の結果となった).

すべての結果をまとめると, Fe粉末の平均残留応力は

$$
\sigma_{\mathrm{Fe}}=-4 \mathrm{MPa} \pm 11.0 \mathrm{MPa}(68.3 \% \text { 信頼限界值 })
$$

$\mathrm{SP}$ 試験片における $x, y$ 両方向を含めた平均残留応力は

$$
\sigma_{\mathrm{SP}}=-643 \mathrm{MPa} \pm 36.9 \mathrm{MPa}(68.3 \% \text { 信頼限界值 })
$$

であった。

以上より，Fe粉末の值はほぼ $0 \mathrm{MPa}$ となり測定条件に依存 せず適切な值となった。またSP試験片では，68.3\%信頼限 界值 $(36.9 \mathrm{MPa})$ は平均残留応力值 $(-643 \mathrm{MPa})$ の $6 \%$ 以 下となり，日常業務で設定している条件で測定した結果と しては良好な測定誤差である。

\section{3 応力測定条件の検討}

適切な応力測定条件とは, 残留応力の $68.3 \%$ 信頼限界值 を基準として, 最短時間でその目的の基準值を満たす応力 測定が行える最低条件を指す。残留応力值及びその測定誤 差（68.3\%信頼限界值）と測定時間に大きく影響する条件 としては（1）回折強度曲線のピーク計数值，(2) X線入射 角点数，(3) $\sin ^{2} \psi$ の範囲の最大值が挙げられる.
そこで個々の条件を系統的に変化させて残留応力測定を 行い，残留応力值及びその測定誤差におよほすす影響につい て検討した。

応力測定条件をTable 2に示す。試験片はRRT試験の試験 片と同時に製作し，別途保管しておいたSP試験片を用いた。 コリメータ寸法は，試験片が平板であることから残留応力 值に影響しないものと考え $\phi 3 \mathrm{~mm}$ とした。また測定は10回 反復して行い，10回の平均残留応力値と平均測定誤差（10 回の残留応力測定時のそれぞれの $68.3 \%$ 信頼限界值の平均 值）を求めた。

Fe粉末についても測定を行ったが，残留応力がない状態 であるので，上述した3つの条件の影響はほとんどなかった 以後, $\mathrm{SP}$ 試験片にのみ限定して論じる。

\subsection{1 回折強度曲線のピーク計数值の影響}

すべての悀でのピーク計数值が一定になるように回折強 度曲線を測定（定ピーク計数法）して応力測定を行った。

ピーク計数值として $250 ， 500 ， 750 ， 1000 ， 1500 ， 2000$ ， 4000カウントの7通りを設定した。なお $\sin ^{2} \psi$ の範囲は $0 \sim 0.7$, $\sin ^{2} \psi$ を0.1扮き $\left(\Delta \sin ^{2} \psi=0.1\right)$ とした。

SP試験片の測定結果をFig. 3に示す。ピーク計数值の影響


増加に伴い，測定誤差 $\Delta \sigma$ は輈減する。図中の実線は累乗回 帰線で回帰結果は以下のと㧍りである。( $R^{2}$ は決定係数 $)$

$\ln (\Delta \sigma)=-0.422 \cdot \ln \left(I_{\mathrm{p}}\right)+5.09 \quad\left(R^{2}=0.970\right)$

これを累乗の形で表すと, 式（1）となる。

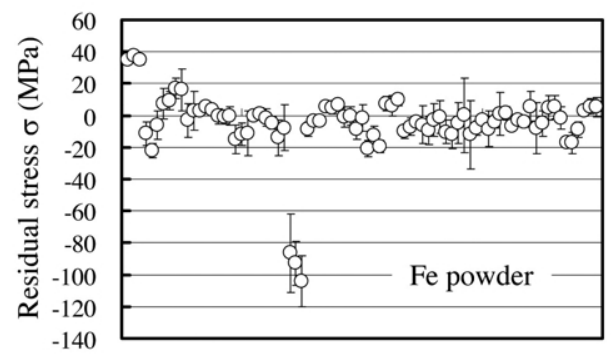

(a) Fe powder.

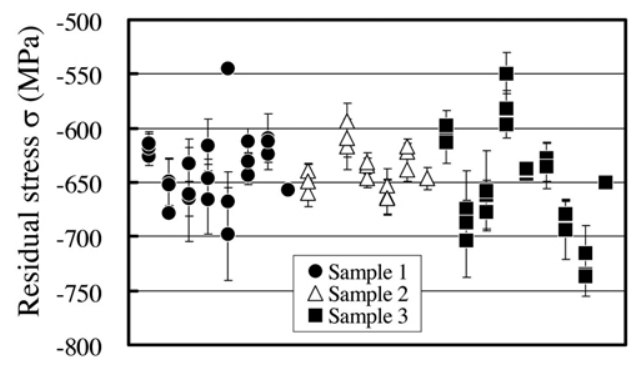

(b) Shot peened specimen.

Fig. 2 Residual stresses of Fe powder and shot peened specimen (SP).

Table 2 Conditions of X-ray stress measurement for shot

\begin{tabular}{|c|c|}
\hline Characteristic X-ray (Filter) & $\mathrm{Cr}-\mathrm{K} \alpha \quad$ (V filter $)$ \\
\hline Diffraction & $\alpha \mathrm{Fe} 211 \quad\left(2 \theta_{0}=156.4 \mathrm{deg}\right)$ \\
\hline Detector $\quad(\mathrm{MCA})$ & PSPC (512 Channels) \\
\hline Measuring method & Iso-inclination method \\
\hline Tube voltage, current & $30 \mathrm{k} \mathrm{V}, \quad 15 \mathrm{~mA}$ \\
\hline Collimator & $\phi 3 \mathrm{~mm}$ \\
\hline Peak determination & FWHM middle point method \\
\hline Diffraction profile treatment & Non Smoothing, Non oscillation \\
\hline $\mathrm{X}$-ray stress constant & $K=-318 \mathrm{MPa} / \mathrm{deg}$ \\
\hline
\end{tabular}
peened plate.

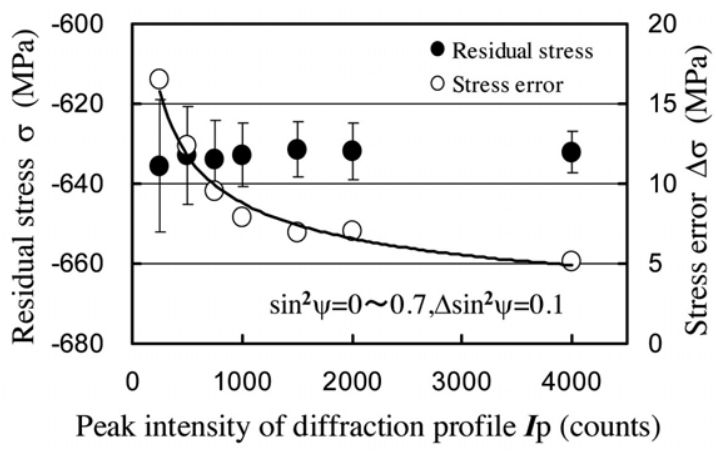

Fig. 3 Effect of peak intensity of diffraction profile on residual stress and its error. 


$$
\Delta \sigma(\mathrm{MPa})=162 I_{\mathrm{p}}^{-0.422}
$$

測定誤差 $\Delta \sigma$ は大まかに統計的な認識どおり $I_{\mathrm{p}}{ }^{-0.5}$ に比例 している。この原因は, 測定誤差 $\Delta \sigma$ は測定された回折強度 曲線におけるピーク近傍のノイズがピーク位置決定に影響 することから生じるものと判断できる.

いま仮に本実験の範囲内で，測定誤差を $\pm 10 \mathrm{MPa}$ (残留 応力值に対して測定誤差が $\pm 2 \%$ 以内）とすると，ピーク計 数值は 1000 カウント上に設定すれば良いという結論を得 る.

ただし，例えばCrK $\beta$ 線によるオーステナイト $\gamma \mathrm{Fe} 311 の$ 回折強度曲線のようにSN比（回折強度/バックグランド強 度）が良好でない場合はバックグランド強度が大きく，ピ ーク計数值だけを考慮するだけでは回折角決定精度の低下 が危惧され，バックグランド強度を差し引いた純粋な回折X 線強度がどの程度必要であるかが問題となる。しかしその ような場合は純粋な回折X線強度が1000カウント以上になれ ば測定誤差が土10MPaになるものと推察できる。

\subsubsection{X線入射角点数の影響}

本実験は $\sin ^{2} \psi$ の範囲を $0 \sim 0.6$ に固定し, $\sin ^{2} \psi$ の設定ステ ップ $\Delta \sin ^{2} \psi$ が等間隔になるよう入射角点数 $N を 4 ， 5 ， 7 ， 9$, 13点の5通り設定した。 また回折強度曲線のピーク計数值は 1000カウントとし，定ピーク計数法で測定した。

Fig. 4に測定結果を示す. 残留応力值についてはあまり入

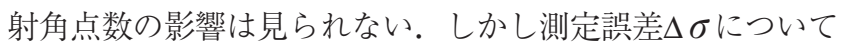
は, 入射角点数Nの増加に伴い漸減する。図中の実線は累 乗回帰線で回帰結果は以下のとおりである.

$$
\ln (\Delta \sigma)=-0.534 \cdot \ln (N)+3.20 \quad\left(R^{2}=0.980\right)
$$

これを累乗の形で表すと，式（2）となる。

$$
\Delta \sigma(\mathrm{MPa})=24.6 N^{-0.534}
$$

ちなみにFe粉末の測定誤差 $\Delta \sigma$ に関してはX線入射角点数 にかかわらず， $\Delta \sigma= \pm 10 \mathrm{MPa}$ 以下となっていた。

したがってFe粉末の測定誤差 $\Delta \sigma$ と同じに， $\mathrm{SP}$ 試験片の $\Delta \sigma$ を $10 \mathrm{MPa}$ とするのであれば，X線入射角点数を5点以 上設定する必要がある。

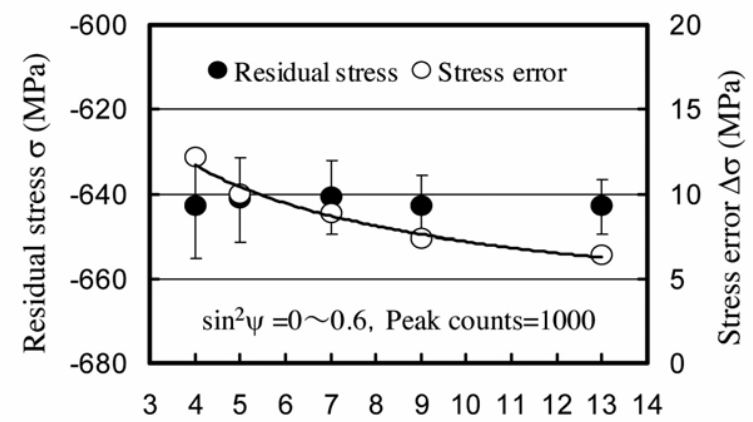

Number of X-ray incident angle $N$ (points)

Fig. 4 Effect of number of X-ray incident angle on residual stress and its error.

\subsection{3 $\sin ^{2} \psi$ 範囲の最大 $\sin ^{2} \psi$ 值の影響}

本実験の $\sin ^{2} \psi$ 範囲を最小 $\sin ^{2} \psi$ 值は 0 とし，最大 $\sin ^{2} \psi$ 值を 0.4，0.5．０.6，0.7に設定し， $\sin ^{2} \psi$ のテップ $\Delta \sin ^{2} \psi$ ス $0.1 己 ゙$ ととした。したがって入射角点数Nは最大 $\sin ^{2} \psi$ 值によって 異なる。また回折強度曲線のピーク計数值は1000カウント に設定した。

Fig. 5にSP試験片の測定結果を示す. 残留応力に関しては, 最大 $\sin ^{2} \psi$ 值 $=0.4$ 以外のときはほぼー640MPa となっている が，最大 $\sin ^{2} \psi$ 值 $=0.4$ では－650MPaとなり若干の相違があ


い，測定誤差は漸減する。そして最大 $\sin ^{2} \psi$ 值 0.5 以上では測 定誤差は $\pm 10 \mathrm{MPa}$ 以下となっている.

本実験の範囲内で測定䛊差 $\Delta \sigma$ を $10 \mathrm{MPa}$ とするのであれ ば，最大 $\sin ^{2} \psi$ 值は0.5以上に設定すべきと考える。ただし本 実験では $\sin ^{2} \psi$ の範囲を 0 から最大 $\sin ^{2} \psi$ 值まで，0.1ごとに設 定しており，最大 $\sin ^{2} \psi$ 值が大きくなるほど，X線入射角点 数が多くなるので最大 $\sin ^{2} \psi$ 值の影響だけでなく，入射角点 数の影響も含まれている.

\subsection{4 応力測定条件の総括}

以上の残留応力と測定時間に影響を及ぼすと考えられる 3 つの測定条件をまとめる。本実験に供したSP試験片（残留 応力值約 $-640 \mathrm{MPa})$ において，平均測定誤差 $\Delta \sigma$ を $\mathrm{Fe}$ 粉末 と同じ值の土 $10 \mathrm{MPa}$ と設定すると以下の条件が適切である.

・回折強度曲線のピーク計数值は1000カウント以上.

・ $\sin ^{2} \psi$ の設定範囲は，最小 $\sin ^{2} \psi$ 值 $=0$ より最大 $\sin ^{2} \psi$ 值は 0.5 以上.

·X線入射角点数は5点以上で， $\sin ^{2} \psi$ のテップ $\Delta \sin ^{2} \psi$ は 等間隔.

この3つの条件を基にSP試験片のRRT測定結果を整理しな おした. Tables 3〜 5にSP試験片の平均残留応力值と平均測 定誤差の整理結果を示す。いずれも表中の左側は各条件を 満たさない場合の結果で右側が条件を満たす場合の結果で ある。いずれの場合も条件を満たす測定結果の平均測定誤 差は減少している。ここでの平均測定誤差とは, 測定され た残留応力值の $68.3 \%$ 信頼限界の平均值である。

日本材料学会「X線応力測定法標準 」) では，「測定におけ る $\sin ^{2} \psi$ の範囲は $0 \sim 0.6$ まで $\sin ^{2} \psi$ 等間隔に 5 点以上設定. 回

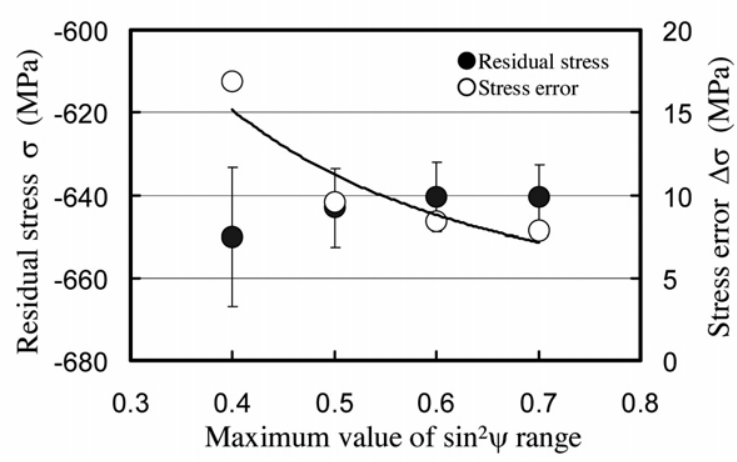

Fig. 5 Effect of maximum value of $\sin ^{2} \psi$ range on residual stress and its error. 
折強度曲線のピーク計数值は 1000 カウン以上」と記述して いるが，この条件がSPばねについても適切であることをは じめて実験的に検証した。

4. ショットピーニング処理された丸棒の残留応力測定

ばね関連企業に行ったX線応力測定の実態調査結果 (Fig. 1 参照）から，コイルばねや弁ばねの残留応力測定の頻度が 比較的多いことが明らかとなっている.

一方，ショットピーニングに関するJIS-B2711の付属書 「残留応力の測定方法」 $\rfloor^{2)}$ でも測定表面が湾曲している場合 の対処法が規定されている。しかし，その内容は「平面と見 なせる程度の面積を残してマスキングする」との表現のみ で，極めて曖昧である。

そこで，第2回RRTとして，コイルばねや弁ばねに使用さ れるばね鋼丸棒試験片の残留応力測定を行い, 残留応力値 に抢よぼす素線径とコリメータ径（X線照射面積）の関係， マスキング (X線照射面の制限) の影響，応力算出のための $\sin ^{2} \psi$ 範囲の検討を行った。

Table 3 The classification of RRT results by peak intensity of diffraction profile.

\begin{tabular}{|c|c|c|}
\hline Item (SP) & $\begin{array}{c}\text { Peak counts } \\
\boldsymbol{I} \mathrm{p}<1000\end{array}$ & $\begin{array}{c}\text { Peak counts } \\
\boldsymbol{I} \mathrm{p} \geqq 1000\end{array}$ \\
\hline $\begin{array}{c}\text { Average of } \\
\text { residual stress }\end{array}$ & $-653 \mathrm{MPa}$ & $-649 \mathrm{MPa}$ \\
\hline Stress error & $\pm 41.6 \mathrm{MPa}$ & $\pm 36.3 \mathrm{MPa}$ \\
\hline
\end{tabular}

Table 4 The classification of RRT results by number of X-ray incident angle.

\begin{tabular}{|c|c|c|}
\hline Item (SP) & Number of $\psi<5$ & Number of $\psi \geqq 5$ \\
\hline $\begin{array}{c}\text { Average of } \\
\text { residual stress }\end{array}$ & $-626 \mathrm{MPa}$ & $-648 \mathrm{MPa}$ \\
\hline Stress error & $\pm 41.3 \mathrm{MPa}$ & $\pm 25.8 \mathrm{MPa}$ \\
\hline
\end{tabular}

Table 5 The classification of RRT results by maximum $\sin ^{2} \psi$ value.

\begin{tabular}{|c|c|c|}
\hline Item (SP) & $\begin{array}{c}\text { Maximum } \sin ^{2} \psi \\
\text { value }<\mathbf{0 . 5}\end{array}$ & $\begin{array}{c}\text { Maximum } \sin ^{2} \psi \\
\text { value } \geqq \mathbf{0 . 5}\end{array}$ \\
\hline $\begin{array}{c}\text { Average of } \\
\text { residual stress }\end{array}$ & $-657 \mathrm{MPa}$ & $-643 \mathrm{MPa}$ \\
\hline Stress error & $\pm 43.9 \mathrm{MPa}$ & $\pm 27.4 \mathrm{MPa}$ \\
\hline
\end{tabular}

Table 6 Shot peening conditions of round-bar samples.

\begin{tabular}{|c|c|c|c|c|c|c|c|c|}
\hline Sample & a & A & b & B & c & C & d & D \\
\hline Steel & SWOSC-V & SUP7 & SWOSC-V & SUP7 & SWOSC-V & SUP7 & SWOSC-V & SUP7 \\
\hline $\begin{array}{c}\text { Diameter } \\
\text { (mm) }\end{array}$ & $\phi 3.5$ & $\phi 11.1$ & $\phi 3.5$ & $\phi 11.1$ & $\phi 3.5$ & $\phi 11.1$ & $\phi 3.5$ & $\phi 11.1$ \\
\hline $\begin{array}{c}\text { Hardness of } \\
\text { shot }\end{array}$ & HV 400-500 & \multicolumn{2}{|c|}{ HV $550-650$} & HV 700-800 & HV $550-650$ \\
\hline $\begin{array}{c}\text { Size of shot } \\
\text { (mm) }\end{array}$ & 0.1 & 0.8 & 0.05 & 0.8 \\
\hline $\begin{array}{c}\text { Air Pressure } \\
\text { (MPa) }\end{array}$ & 0.2 & 0.2 & 0.2 & 0.2 \\
\hline $\begin{array}{c}\text { Coverage } \\
(\%)\end{array}$ & 200 & 200 & 200 & 1000 \\
\hline $\begin{array}{c}\text { Arc height } \\
\text { (mmA) }\end{array}$ & 0.187 & 0.455 & 0.162 & 0.582 \\
\hline
\end{tabular}

\section{1 供試材及び試験片}

本実験に供した材料は，弁ばね用OT線 SWOSC-V ( $\phi 3.5)$ ， 懸架ばね用OT線 SUP7 ( $\phi 11.1)$ である。この材料にショ ットピーニングを施工し，深さ方向の残留応力分布が異な る試験片を準備した。供試材料及びショットピーニング条 件の相違による試験片の種類をTable 6に示す。試験片 $\mathrm{a} \cdot \mathrm{A}$, $\mathrm{b}$ ・Bは，一般的にばねに使用されるショットサイズを用い


ヨットサイズを用いた条件であり，試験片 $\mathrm{d} \cdot \mathrm{D}$ は，条件 $\mathrm{b}$ ・ Bよりカバレージを大きくしたものである。ショットピ ーニング処理の概略図をFig. 6に示す。試験片を回転させ, 直圧式ショットピーニングマシンにて全周に投射した。

$\mathrm{X}$ 線応力測定の条件は，第 3 章に記述した平板の残留応力 （第1回RRT）の検討結果を基準として，測定条件に制限を 設けた。Table 7にX線測定条件を示す。

測定試験片は各3個製作し，参加機関は委員会メンバー9 機関にて実施した。な㧍，試験片については同条件でショ ットピーニングを施工していることから，試験片間の差は ないものとし，デー夕を整理した。

\section{2 素線径とコリメータ径の関係}

残留応力測定には試験片 $\mathrm{b}$ ・ Bを用いた。照射寸法は $\phi 0.5$, $\phi 1.0 ， \phi 2.0 ， \phi 4.0$ (試験片Bのみ) のコリメー夕を使用し, $\sin ^{2} \psi$ 範囲は $0 \sim 0.60$ (等間隔に $\Delta \sin ^{2} \psi=0.12$ 扮きに入射点数 6 点) とした。

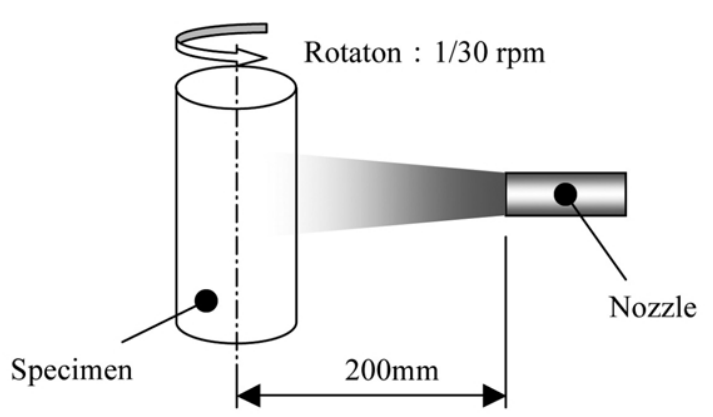

Fig. 6 Schema of shot peening.

Table 7 Conditions of X-ray stress measurement for round bar.

\begin{tabular}{|c|c|}
\hline Characteristic X-ray (Filter) & $\mathrm{Cr}-\mathrm{K} \alpha \quad$ (V filter $)$ \\
\hline Diffraction & $\alpha \mathrm{Fe} 211 \quad\left(2 \theta_{0}=156.4 \mathrm{deg}\right)$ \\
\hline Detector (MCA) & PSPC (>512 Channels) \\
\hline Measuring method & Iso-inclination method \\
\hline Tube voltage, current & $30 \pm 10 \mathrm{k} \mathrm{V}, \quad 10 \sim 40 \mathrm{~mA}$ \\
\hline $\sin ^{2} \psi$ range, ( even step) & $0-0.60,\left(\Delta \sin ^{2} \psi=0.12,6\right.$ points $)$ \\
\hline Peak counts & $>1000$ counts \\
\hline Peak determination & FWHM middle point method \\
\hline Diffraction profile treatment & Non Smoothing, Non oscillation \\
\hline Measuring direction & Axial, 45 deg along axial, Hoop \\
\hline $\mathrm{X}$-ray stress constant & $K=-318 \mathrm{MPa} / \mathrm{deg}$ \\
\hline
\end{tabular}


測定結果をFig. 7に示す. 図中のマークは平均残留応力值 で, 縦方向の線分は測定された最大, 最小の残留応力範囲 を示している，X線照射面積の増加にともない，圧縮残留応 力值が低下する傾向がある．特にこの傾向が顕著に認めら れたのは線径の小さい試験片bである。また，測定方向につ いては, 長手方向 $<45^{\circ}$ 方向 $<$ 周方向の順に圧縮残留応力值 の低下が大きくなった。本結果より, 丸棒の残留応力を測 定する際には，照射面積と線径の影響だけでなく，測定方 向にも配慮が必要であることが判った。

小栗らは正方形のX線照射面寸法 $\square 2 \zeta$ と線径 $\phi 2 \rho$ の比（ $\zeta$ $/ \rho)$ と測定応力值/実残留応力值の比 $\left(\sigma_{\text {measured }} / \sigma_{\text {actual }}\right)$ の関 係を検討している ${ }^{4)}$. 小栗らの研究と同様に, 本実験で得ら れた結果をコリメータ径 $2 \zeta /$ 線径 $2 \rho$ の比と測定応力值/実残
留応力值比で整理した。 ただし，実残留応力は最小コリメ ー夕径（ $\phi 0.5 ）$ で得られた応力值とした. 結果をFig. 8に示 す。本委員会の結果は, 小栗が線侵入深さやX線光学系を 考慮して解析した式と良く一致している。したがって，コ

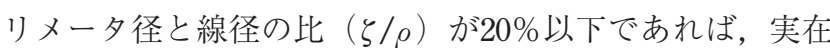
する残留応力值との差が10\%以下になることを確認した。

\section{3 マスキングの影響}

マスキングの影響を検討するため，試験片 $\mathrm{b} \cdot \mathrm{B}$ の残留応 力測定を行った。測定には， $\phi 1.0$ のコリメータを使用し，

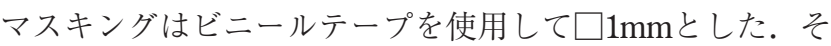
の他の測定条件はTable 7と同様である.

測定結果をFig. 9に示す.また測定された残留応力の平均 值をTable 8に示す。マスキングありでは，マスキングなし

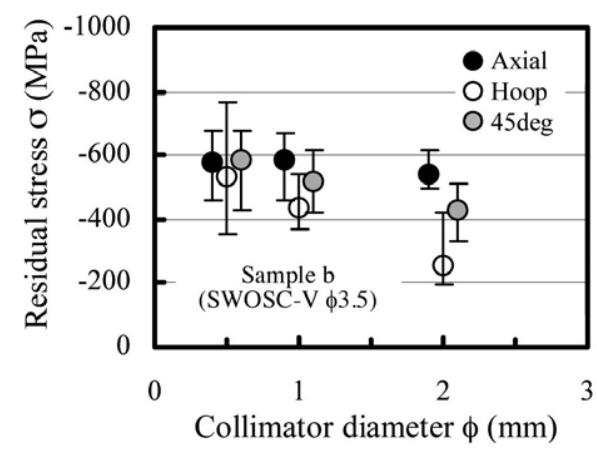

(a) Sample b

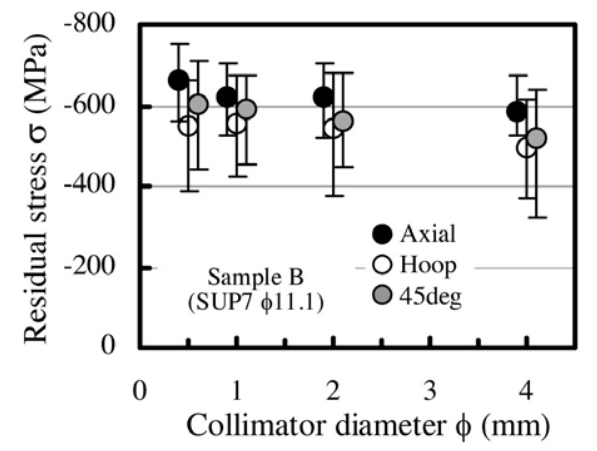

(b) Sample B

Fig. 7 Relation between residual stress and collimator diameter.

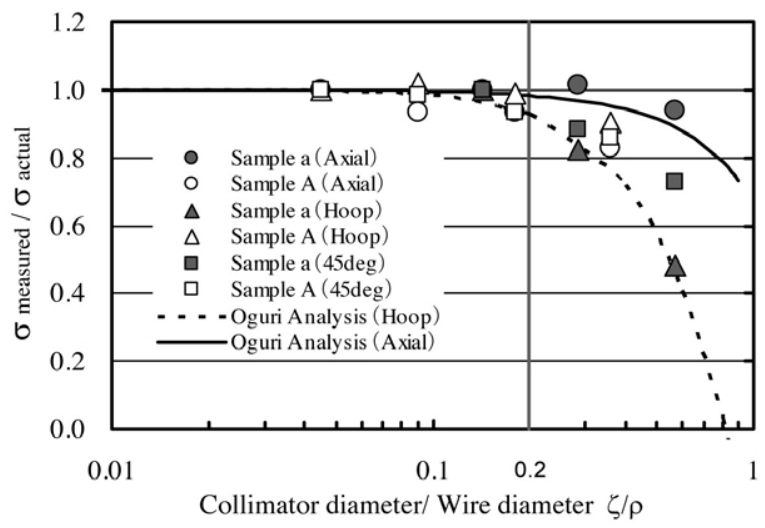

Fig. 8 Relation between normalized residual stress and normalized irradiation size.

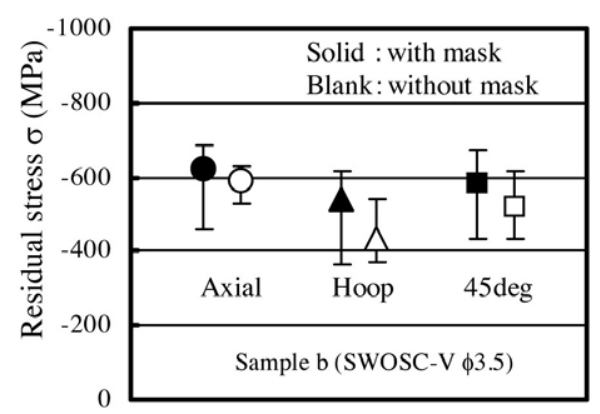

(a) Sample b

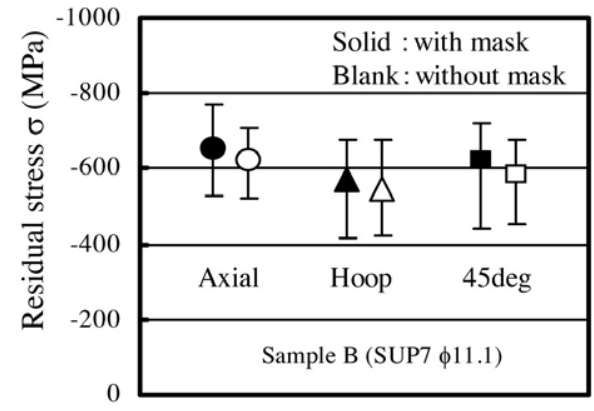

(b) Sample B

Fig. 9 Effect of X-ray irradiation mask on residual stresses. 
に比べて平均圧縮残留応力值が30 100MPa程度高い值を示 した。 その傾向は, 線径の小さい弁ばね材のほうが顕著で あった。この原因は，コリメータの場合にX線入射角せを大 きくしていくと，X線照射面の形状が長軸方向に伸びた楕円 となり，回折に寄与する結晶が多くなることにある。した がって，悀ごとに照射面積が異なることとなり，照射面内 の表面応力が大きく変化したり，表面に曲率があるような 場合は, 応力測定原理上からも好ましくなく, 測定応力值 の信頼度が低下することは明らかである。

一方，マスキングを行った場合には，一測定内において， 悀に関わらず照射面積は常に一定であり，得られる応力值 は照射面内の平均值として評価することができる.

以上のことから，コイルばねや弁ばねのような表面に曲 率を有する試料に実在する残留応力值を測定するためには, マスキングを行うことが重要な条件となる。

\section{4 応力算出のための $\sin ^{2} \psi$ 範囲の影響}

Table 6に示したすべての試験片の残留応力測定を行った. 測定条件はTable 7に準じたが， $\sin ^{2} \psi$ 範囲に関しては $0 \sim 0.65\left(\Delta \sin ^{2} \psi=0.05\right.$ ，入射角 14 点） とした. Fig. 10に $\sin ^{2} \psi$ 線図の一例を示す。試験片a・A，c・ Cのすべての $\sin ^{2} \psi$ 線図で，この図と同様に $\sin ^{2} \psi$ 線図が非直 線となることが認められた。また， $\sin ^{2} \psi$ 線図には測定方向 特有の傾向があることも確認された。いずれも $\sin ^{2} \psi=0$ 0.3 の範囲に特徵が認められ，長手方向では上に凸，周方向 では下に凸，45度方向についてはその中間の形状となって いる。

一方，試験片 b・B，d・Dについては $\sin ^{2} \psi$ 線図が湾曲す るような傾向は見られなかった。
本委員会では応力算出のための $\sin ^{2} \psi$ 範囲の影響を調べる 目的で，応力の算出を $\sin ^{2} \psi$ 範囲で $0 \sim 0.3,0.3 \sim 0.6, \quad 0 \sim 0.65$ と3条件に分けて比較検討を行い，すでに報告を行った ${ }^{5)}$.

しかし，Fig. 10のように明確な湾曲を有する $\sin ^{2} \psi$ 線図に 対して，例え $\sin ^{2} \psi$ 範囲を区分し $\sin ^{2} \psi$ 法による応力算出（直 線回帰）をしても，得られる応力值の評価は意味をもたな い. 本来は $\sin ^{2} \psi$ 線図が湾曲した原因を明確にした上で，そ れぞれの原因に応じた残留応力の測定法を適用する必要が ある。

一般的に $\sin ^{2} \psi$ 線図が湾曲する原因は，（1）表面下のX線 侵入深さ内に等二軸で急峻な応力勾配を有する場合 ${ }^{6)}$,

(2) 表面下のX線侵入深さ内に深さ方向のせん断応力成分を 有する三軸応力状態の場合（例えば研削などの有向性加工） 7)，あるいは (3) 集合組織を有する場合 ${ }^{8)}$ などがある.

\section{$4.5 \sin ^{2} \psi$ 線図の非直線性について}

第2回RRTでは，小さなショット径のピーニングの場合 (試験片 $\mathrm{a} \cdot \mathrm{A}, \mathrm{c} \cdot \mathrm{C}$ ) に, $\sin ^{2} \psi$ 線図の非直線性が現れること がわかった。

そこで，その原因を明らかし，このような場合にどのよ うな残留応力解析を行わなければならないのかについて検 討した。

\subsection{1 実験方法}

X線応力測定は本委員会メンバーの 4 機関で実施した。 実験は第2回RRTと同じ試験片を用いた。X線測定条件は 4.4 節と同条件とした。なお，本実験の測定方向は長手（軸） 方向のみとした。

ショットピーニング後の深さ方向の $\sin ^{2} \psi$ 線図の変化を調 査する目的で，試験片表面を5〜30 $\mu \mathrm{m}$ まで $5 \mu \mathrm{m}$ おきに化学

Table 8 Average residual stresses measured with and without X-ray mask.

\begin{tabular}{|c|c|c|c|c|c|c|}
\hline Item & \multicolumn{3}{|c|}{ Sample b } & \multicolumn{3}{c|}{ Sample B } \\
\hline Stress direction & Axial & Hoop & $45^{\circ}$ & Axial & Hoop & $45^{\circ}$ \\
\hline Stress with mask (MPa) & -624 & -538 & -582 & -650 & -574 & -623 \\
\hline Stress without mask (MPa) & -591 & -435 & -521 & -624 & -549 & -586 \\
\hline
\end{tabular}

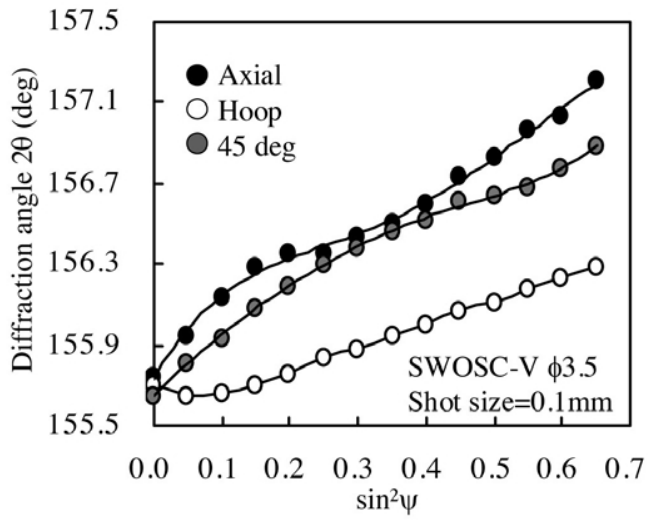

(a) Sample a

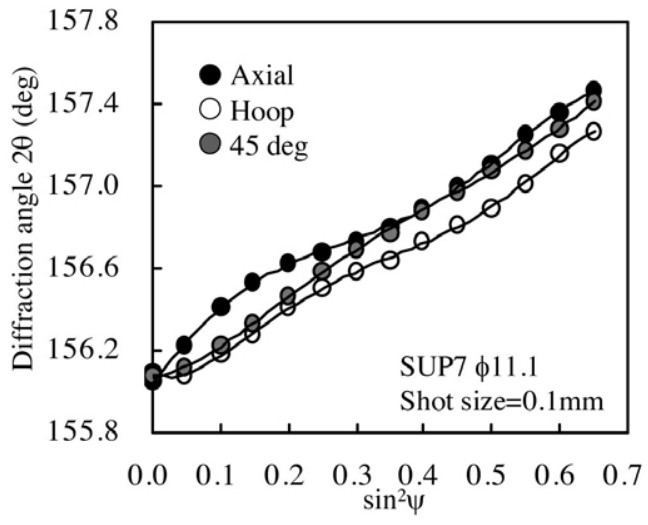

(b) Sample A

Fig. $102 \theta-\sin ^{2} \psi$ diagrams in various measuring directions. 
研磨または電解研磨を行い, $\sin ^{2} \psi$ 線図の形態を観察した。

測定データは $\sin ^{2} \psi$ 線図とX線計数率一 $\sin ^{2} \psi$ 線図（以後計 数率線図と呼ぶ）を求めた。ただし計数率はピーク計数值 $\left(I_{\mathrm{p}}\right.$ counts $)$ を計数時間 $(t \mathrm{sec})$ で除した值 $(\mathrm{cps})$ とした。

\subsection{2 深さ方向の $\sin ^{2} \psi$ 線図の変化}

結果の一例としてFig. 11, Fig. 12にそれぞれ試験片B, 試 験片Aの $\sin ^{2} \psi$ 線図, 計数率線図を示す.

Fig. 11に示した試験片Bの $\sin ^{2} \psi$ 線図は電解研磨深さに関 係なく $\sin ^{2} \psi に$ 対してほぼ直線となっており，計数率線図は $\sin ^{2} \psi$ の増加に伴い単調減少している.

$\sin ^{2} \psi$ 法による応力測定が可能な試料の条件は, ランダム 配向（等方）された多結晶体で，任意な山角においてX線照 射面積内に回折に寄与する充分な数の結晶粒が均一に存在 (均質) することが挙げられる。そしてX線侵入深さ内で平 面応力状態が成立し, 急峻な応力変化 ${ }^{6)}$ が存在してないと き, $\sin ^{2} \psi$ 線図は直線となる。

またあらゆる解において, 回折に寄与する結晶粒が均一 に存在する場合, 本来角に依存せず回折X線の強度は等し くなる。しかし回折X線の強度が等しくても，悀が大きく なるにしたがい, 試料表面から材料内を通過するX線光路長

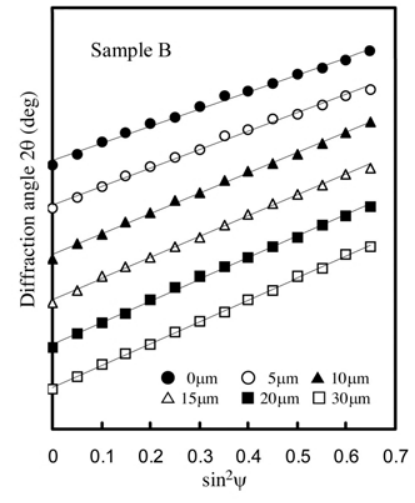

(a) $2 \theta-\sin ^{2} \psi$ diagram.

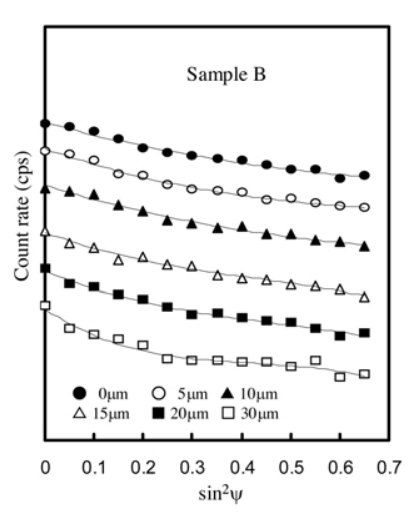

(b) Count rate-sin $\sin ^{2} \psi$ diagram.
Fig. 11 Shape change of $2 \theta-\sin ^{2} \psi$ and count rate $-\sin ^{2} \psi$ diagrams in depth direction.

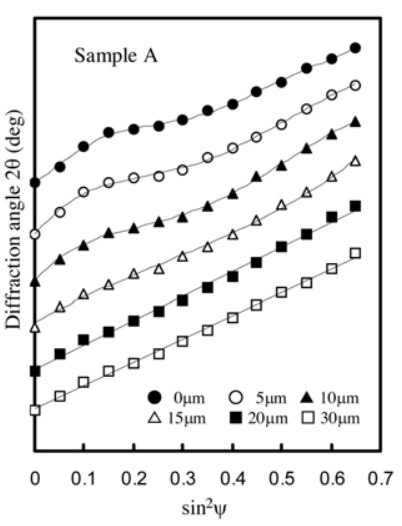

(a) $2 \theta-\sin ^{2} \psi$ diagram.

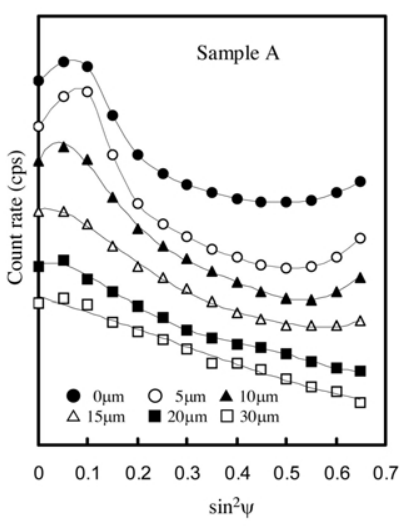

(b) Count rate-sin ${ }^{2} \psi$ diagram.
Fig. 12 Shape change of $2 \theta-\sin ^{2} \psi$ and count rate $-\sin ^{2} \psi$ diagrams in depth direction.
(入射X線及び回折X線の通過距離) が長くなり，材料へのX 線吸収が大きくなる。結果として廿角が大きくなるにしたが い計数率（回折X線強度）は減少する。すなわち $\sin ^{2} \psi$ 法に よる応力測定が可能な場合の計数率線図は $\sin ^{2} \psi$ 值の増加に 伴い計数率は漸減する状態を呈する.

改めて, Fig. 11に示した試験片Bの計数率線図及び $\sin ^{2} \psi$ 線図から判断して, 試験片Bは無秩序に配向された結晶状 態で, X線侵入深さ内で平面応力状態かつ応力変化がなく, $\sin ^{2} \psi$ 法による応力算出が健全に行えると判断できる.

しかし, Fig. 12に示した試験片Aの計数率線図は表面から $15 \mu \mathrm{m}$ 深さまでうねりを有する状態となっている。した がって試験片Aは $\sin ^{2} \psi$ 法による応力算出が行える結晶状態 ではなく，この影響で表面から $15 \mu \mathrm{m}$ の深さまでの $\sin ^{2} \psi$ 線 図は直線となっていないものと推察される。

\subsection{3 組織観察}

Fig. 12で示したように試験片Aの表面から深さ $15 \mu \mathrm{m}$ まで は, 計数率線図から判断して, $\sin ^{2} \psi$ 法が適用できる状態で はない。

そこで試験片Aの断面観察を行った. Fig. 13に試験片Aの 組織写真を示す。この写真から最表面に白層が確認された. その厚さは20〜 $30 \mu \mathrm{m}$ 程度であるが, 全表面を覆っているわ けではなかった、ショットピーニングに代表される強ひず みを導入できる加工により，鉄鋼材料に白層と呼ばれるナ

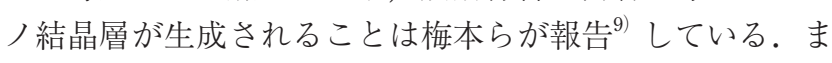
た，ショットピーニングにより，ばね材に発生する白層の

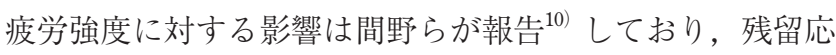
力の測定も行っているが, $\sin ^{2} \psi$ 線図での非直線性について は言及していない.

Table 9に今回の測定で得られた $\sin ^{2} \psi$ 線図の直線性の喪 失, 計数率線図のうねりの存在と断面観察による白層の有 無をまとめる。この表からショットピーニング条件として は，粒径の小さなショットを使用した条件（試験片 $\mathrm{a} \cdot \mathrm{A}$, c・C）において白層が生成していることがわかる.

白層の厚さと $\sin ^{2} \psi$ 線図の直線性が回復する深さがほぼ一 致することから, 表面における白層の存在が $\sin ^{2} \psi$ 線図及び 計数率線図の形状に影響を与えていると推察できる.

特性X線 $\mathrm{CrK} \alpha$ で $\alpha \mathrm{Fe} 211$ 回折を測定する場合のX線侵入深 さは $\sin ^{2} \psi=0 \sim 0.65$ でほぼ $5.5 \mu \mathrm{m} \sim 4.5 \mu \mathrm{m}$ であり，その侵入



Fig. 13 Microphotograph of cross section in the shot peened surface of Sample A. 
Table 9 Shape of $2 \theta-\sin ^{2} \psi$ and count rate- $\sin ^{2} \psi$ diagrams and existence of white layer.

\begin{tabular}{|c|c|c|c||c|c|c|c|}
\hline Sample & $\begin{array}{c}\sin ^{2} \psi \\
\text { diagram }\end{array}$ & $\begin{array}{c}\text { Count rate } \\
\text { diagram }\end{array}$ & $\begin{array}{c}\text { White } \\
\text { layer }\end{array}$ & Sample & $\begin{array}{c}\sin ^{2} \psi \\
\text { diagram }\end{array}$ & $\begin{array}{c}\text { Count rate } \\
\text { diagram }\end{array}$ & $\begin{array}{c}\text { White } \\
\text { layer }\end{array}$ \\
\hline a & Nonlinear & Bumpy & Detected & $\mathrm{c}$ & Nonlinear & Bumpy & Detected \\
\hline A & Nonlinear & Bumpy & Detected & C & Nonlinear & Bumpy & Detected \\
\hline b & Linear & Decrescent & None & $\mathrm{d}$ & Linear & Decrescent & None \\
\hline B & Linear & Decrescent & None & D & Linear & Decrescent & None \\
\hline
\end{tabular}

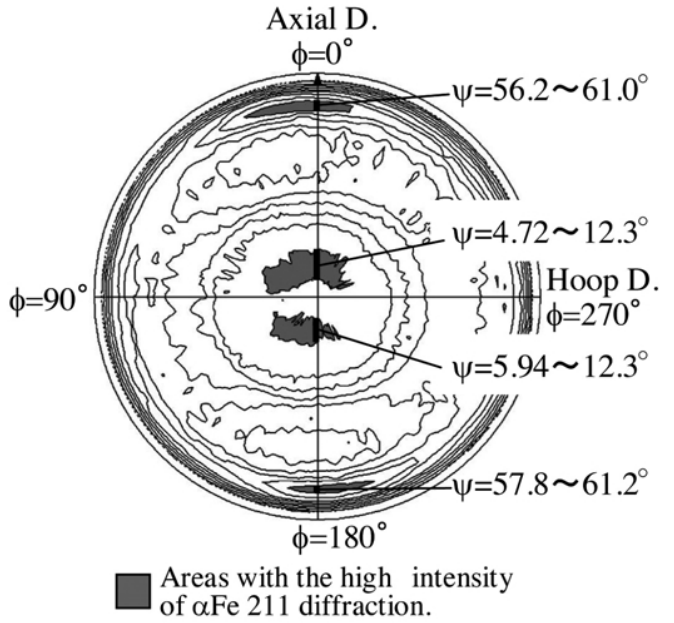

Fig. 14 Pole figure of $\alpha \mathrm{Fe} 211$ on the Sample A by using $\mathrm{Co} \mathrm{K} \alpha$ radiation.

深さ内に白層が存在する場合は白層の回折強度曲線を測定 していることとなる. 改めて試験片表面近傍の計数率線図 の形状（Fig. 12を参照）を観察すると， $\sin ^{2} \psi$ 值が0.5以上で 計数率が上昇する傾向が確認できる。ある特定の悀で計数 率が大きくなる現象は，測定回折面がその特定な山角で特に 多く存在することを意味する。したがって白層の結晶状態 はランダム配向されてなく, 集合組織となっている可能性 が充分考えられる.

そこで, 試験片Aの表面の極点図を特性X線 $\operatorname{CoK} \alpha$ 線で測 定した。 Fig. 14にその結果を示す。また丸棒試験片の座標 系をFig. 15に示す. Fig. 15 の $\phi=0^{\circ}, 180^{\circ}$ は丸棒の軸方向を 表し, $\phi=90^{\circ}, 270^{\circ}$ は周方向を示す.

ショットピーニングした丸棒の軸方向には $\alpha \mathrm{Fe} 211$ 回折に よる回折強度が大きな領域が存在する. $\phi=0^{\circ}, 180^{\circ}$ 軸上で 大きな 211 回折強度を示す $\psi$ 角の範囲は $\psi=4.2 \sim 12.3^{\circ}$ 及び $\psi=51.2 \sim 61.2^{\circ}$ である。通常，立方晶の（111）面を中心と する標準ステレオ投影図において，無ひずみの211回折は （111）面と (211）面の面間角 $\psi=19.5^{\circ} ， 61.9^{\circ}$ に現れる. Fig. 14に示した試験片Aは表面に大きなひずみを有している ので解がシフトすることを考慮すると, 試験片 $\mathrm{A} の$ 軸方向 上の表面には，表面法線方向に（111）面が存在する集合組 織となっていることが充分推定できる.

一方， $\phi=90^{\circ}, 270^{\circ}$ の周方向の軸上には大きな 211 回折強 度を示す悀は存在しない。

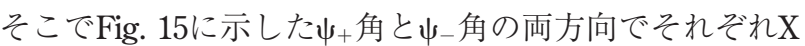

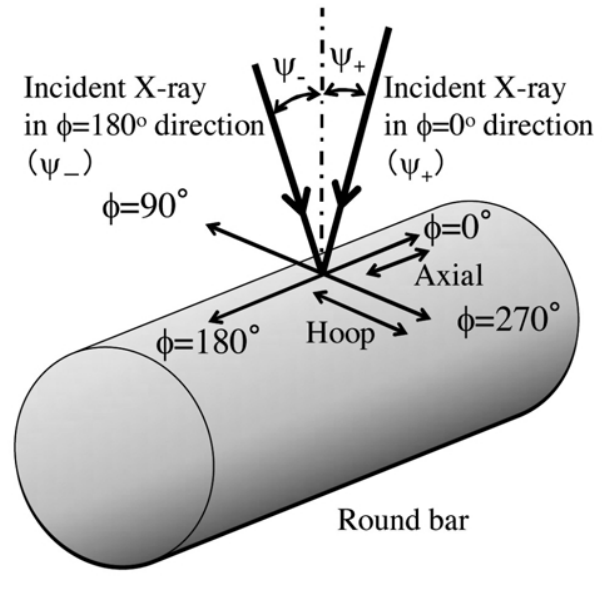

Fig. 15 The layout of coordinate system for round bar.

線を入射させて, 軸方向 $\phi=0^{\circ}$ ( $\psi_{+}$角方向 $), \phi=180^{\circ}$ ( $\psi_{-}$角) の $\sin ^{2} \psi$ 線図，計数率線図を測定した。また周方向 $\phi=90^{\circ}$ $\left(\psi_{+}\right.$角方向 $), \phi=270^{\circ}$ ( $\psi_{-}$角方向) についても同様に設定し て測定した。

Fig. 16に軸方向の測定結果を示す. $\sin ^{2} \psi$ 線困には $\psi_{+}$角と 廿_角の設定にかかわらず $\sin ^{2} \psi$ が 0.3 よりも小さい範囲で明瞭 に上に凸の形状を示しており，Fig. 12で観察された $\sin ^{2} \psi$ 線 図の湾曲は集合組織のために現れた現象であることが明ら

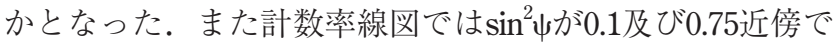
それぞれ計数率のピークがある。これはFig. 14の極点図の 軸方向上の回折強度分布を示している。

したがって軸方向の残留応力を求めるとき，すべての $\sin ^{2} \psi$ 值における回折角 $2 \theta$ を用いて応力を算出する $\sin ^{2} \psi$ 法の 適用はできない。このような場合は，単一の集合組織に属 する 2 点の悀での 2 点の回折角 $2 \theta$ から求めた傾きから残留 応力を決定する必要がある。具体的な方法は，Fig. 16に示 した計数率線図で $\psi=19.5^{\circ}\left(\sin ^{2} \psi=0.11\right)$ 近傍及び $\psi=61.9^{\circ}$ $\left(\sin ^{2} \psi=0.78\right)$ 近傍において, 計数率が極大となる $\sin ^{2} \psi$ 值を 正確に求める。そして，その $\sin ^{2} \psi$ 值における2点の回折角 2 $\theta$ から傾きを求め, 応力を算出しなければならない ${ }^{8)}$.

一方，周方向の $\sin ^{2} \psi$ 線図と計数率線図をFig. 17に示す. $\phi=270^{\circ}$ ( $\psi_{-}$角) 方向の計数率線図には若干集合組織の影響 が出ているが，その程度は少ない。そして， $\sin ^{2} \psi$ 線図をみ ると，X線入射角設定方向 ( $\psi_{+}$角と $\psi_{-}$角) の違いで， $\sin ^{2} \psi$ 線図が明瞭に分離している。この現象は“廿スプリット”と 


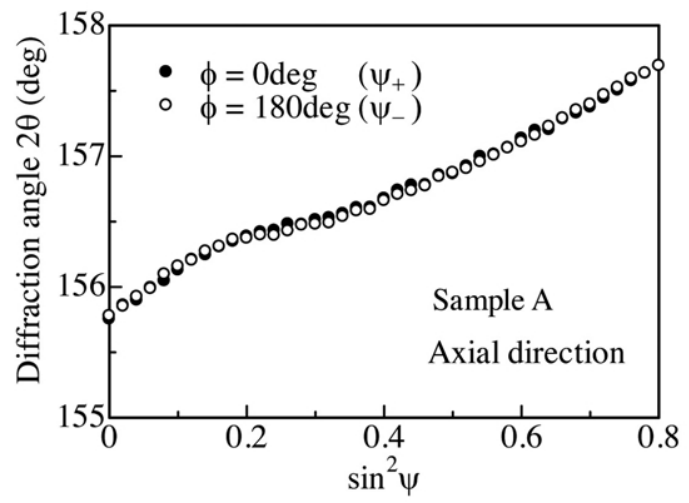

(a) $2 \theta-\sin ^{2} \psi$ diagram.

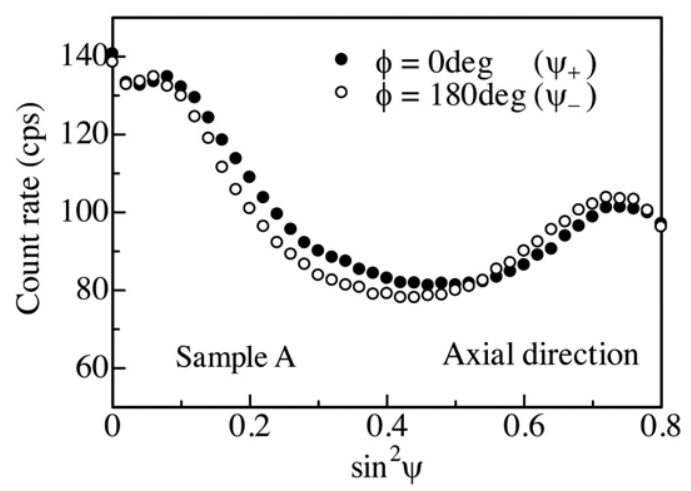

(b) Count rate-sin $\sin ^{2} \psi$ diagram.

Fig. $162 \theta-\sin ^{2} \psi$ and count rate-sin $\sin ^{2} \psi$ diagrams of sample $A$ in the axial direction.

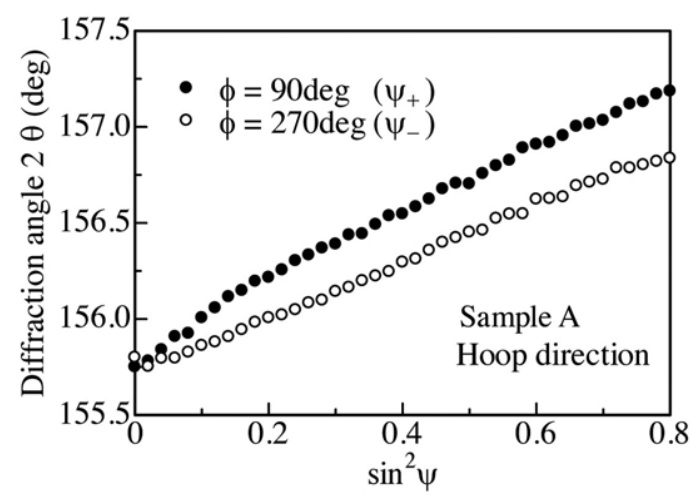

(a) $2 \theta-\sin ^{2} \psi$ diagram.

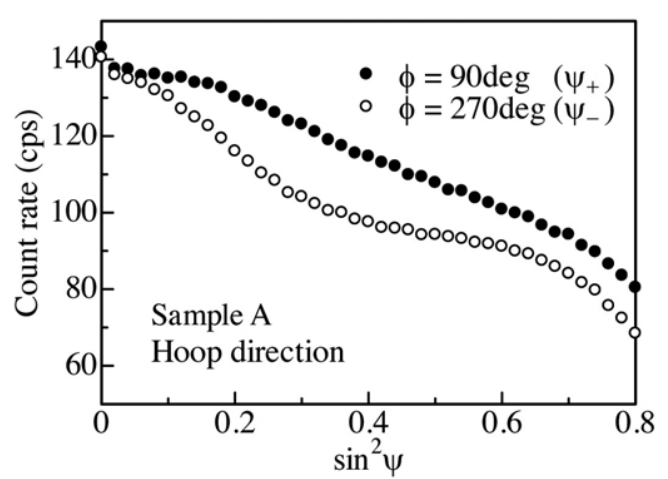

(b) Count rate- $\sin ^{2} \psi$ diagram.

Fig. $172 \theta-\sin ^{2} \psi$ and count rate- $\sin ^{2} \psi$ diagrams of sample $A$ in the hoop direction.

呼ばれ，方向性を持った加工によりX線侵入深さ内に深さ方 向のせん断応力成分を有する三軸応力状態になっているこ とを意味する。

Fig. 17のように $\sin ^{2} \psi$ 線図に廿スプリットが現れる場合, 周 方向の残留応力を $\sin ^{2} \psi$ 法により応力算出を行うと, X線入 射方向 ( $\psi+$ 角, $\psi$-角) の違いによって得られる残留応力值 が異なることが懸念される。

本来， $\psi$ スプリットが起っている場合は三軸応力解析 $\left(\phi=0^{\circ} \sim 315^{\circ}, \Delta \phi=45^{\circ}\right.$ おきに回折強度曲線の測定が必要 $)$ 例えば7) を行い，すべての応力成分を求めた上で，周方向

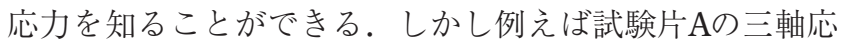
力解析を想定すると, 軸方向 $\left(\phi=0^{\circ}, \phi=180^{\circ}\right)$ に集合組 織が存在するので, 健全な回折強度曲線が測定できず三軸

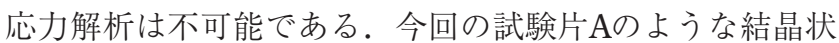
態の応力測定は現状では困難であり, 今後の重要な課題で ある。

以上のことから，コイルばねや弁ばねのように測定表面 が曲率を有する場合の残留応力測定では, ショットピーニ ング施工方法・条件によっては, 試料表面は複雑な結晶状 態 (集合組織) や複雑な応力状態（《スプリットあるいはX 線侵入深さ内に急峻な応力勾配が存在）になっている可能 性がある。
したがって，ルーチンワークとしての残留応力測定を行 う事前作業として，計数率線図が漸減しているかどうか (Fig. 11のようであること)，またX線入射方向（ $\psi_{+}$角， $\psi_{-}$ 角）を換えて $\sin ^{2} \psi$ 線図を測定し廿スプリットが存在しない (Fig. 17の $\sin ^{2} \psi$ 線図のようでない) ことを観察した上で，は じめて $\sin ^{2} \psi$ 法による応力測定法の適用が行えることを確認 する必要がある。

\section{6 丸棒の残留応力測定法のまとめ}

コイルばねや弁ばねを想定して，丸棒のX線応力測定方 法を検討した。

X線コリメー夕径を素線径の $20 \%$ 以下にすることで，実在 する残留応力值との差を $10 \%$ 以下にできることがわかった. さらに,真值に近い残留応力值を測定するためには,限定され たX線照射面からの回折X線を測定することが測定原理上か らも望ましく，測定領域にマスキングをすることが必要で ある。

丸棒にショットピーニングを行うと，その条件によって は $\sin ^{2} \psi$ 線図に非直線性が現れ，かつ計数率線図もうねりを 持つことがわかった。本実験でこれに該当した試験片は， 軸方向に集合組織が存在し，また周方向の応力状態が三軸 状態となっていることがわかった。

コイルばねや弁ばねのように測定表面が曲率を有する場 
合，品質管理などの目的で行う通常の $\sin ^{2} \psi$ 法による残留応 力測定を行う事前作業として, 計数率線図が漸減している かどうか，また $\sin ^{2} \psi$ 線図から廿スプリットや湾曲が存在し ないことを確認することが必要である。

\section{5. $\sin ^{2} \psi$ 線図における非直線度の評価}

従来の $\sin ^{2} \psi$ 法の応力測定における $\sin ^{2} \psi$ 線図の評価は単に その直線性とその傾きの誤差を把握するのみであった。

しかし，4章で示したように， $\sin ^{2} \psi$ 線図はショットピーニ ング条件によっては非直線状態となり，非直線度を示すパ ラメータによる評価が要望される.

本章では，まず $\sin ^{2} \psi$ 線図の回帰直線の不確かさを分析す る量として，曲がりやうねりの評価を行うことを提案した。 そしてX線侵入深さ内の応力状態に起因する $\sin ^{2} \psi$ 線図の曲 がりとうねりがどの程度であれば, $\sin ^{2} \psi$ 法で求めた応力值 で問題がないかどうかについて検討した。

\section{$5.1 \sin ^{2} \psi$ 線図の曲がり度とうねり度の統計学的評価}

\subsection{1 $\sin ^{2} \psi$ 法による応力値の不確かさ}

$\sin ^{2} \psi$ 法による残留応力測定值に対する不確かさの考え方 には，いろいろなものがある、おもなものを挙げると，次 の4つがある。

(1) 総合誤差：同一ロットの材料中で, 試料, 測定法, 測定機関，機器の不同を含む值のばらつき，

\section{General uncertainty}

(2) 一般誤差：個別の単一の測定で, $\sin ^{2} \psi$ 線図上の回帰 直線に対するデータのばらつき, Residual error

(3) 勾配誤差：一般誤差のうち, 回帰直線の勾配につい ての不確かさ, Slope uncertainty

(4) 非直線度：勾配誤差のうち，回帰直線に対する曲が りやうねり等の系統的な非直線性の度合い,

\section{Non-linearity}

まず，一般の技術者からは最も自然な発想である(1)の総 合誤差は，同一ロットの複数試料を複数機関が各自の手法 で測定したときのばらつきで，試料調製上の問題や測定方 法の不同も含む総合的な誤差である．第 3 章で述べたショ ットピーニングを施したばね鋼SUP 9平板試験片について は，具体的な測定方法を特に規制せずに18機関が 22 装置に より各6回ずつの繰返し測定を行ったところ，平均一 $643 \mathrm{MPa}$ ，誤差 $6 \%$ 以下という值が得られている。これは， 確率論的に明らかな異常值を示した1装置のデータを除外し た残りについての標準誤差の值である。

一方，測定技術者が重視する(3)の勾配誤差は，日本材料 学会が定めている特性值で, $\sin ^{2} \psi$ 線図における回帰直線勾 配の標準誤差を意味する。ただし同学会では，これにX線応 力定数を掛けて応力単位で表示し，68.3\%信頼限界值と称 している。2005年に制定されたJIS B 2711ショットピーニン グ規格でもこの考え方を踏襲しているが，結果は相対值と して\%単位で表示する点が異なる。なお本章で後に触れる ように，(3)の勾配誤差は(2)の一般誤差と同等の特性值であ り，かつそれよりはやや大き目の值である。
さらに，測定技術者の要求として，データのばらつきが 回帰直線に対し，どのように系統的な曲がりをもつか，ま たは，うねりがあるか，といった(4)の非直線度を把握した いというニーズがある。それは一般誤差や勾配誤差の原因 を分析する上で，有用である可能性があるからである。

回帰直線の妥当性は, 一般に決定係数Coefficient of determination， $R^{2}$ もって評価する。ここでは，非直線度を $R^{2}$ により数量として表現する方法を提案する.

\subsection{2一般誤差と勾配誤差}

$x_{i}=\sin ^{2} \psi_{i}, y_{i}=2 \theta_{i}$ とおく.ただし $i=1,2, \cdot ・ \cdot n$ で， $n$ は一測定におけるX線入射角 $\psi$ の数とする。 $y$ の単位は角度 (deg) であるから，測定面の性状によっては山角の精度それ 自身が誤差の要因になる可能性があるが，ここではこの問 題は取り上げない. $\sin ^{2} \psi$ 法による応力測定では，yのxに対 する回帰直線を求めるが，その際の回帰モデルは次のよう

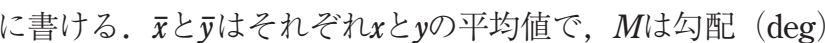
である。

$$
y=M(x-\bar{x})+\bar{y}
$$

$x, y$ の平方和 $S S X$ と $S S Y$ ，積和 $S X Y$ は，次のようになる

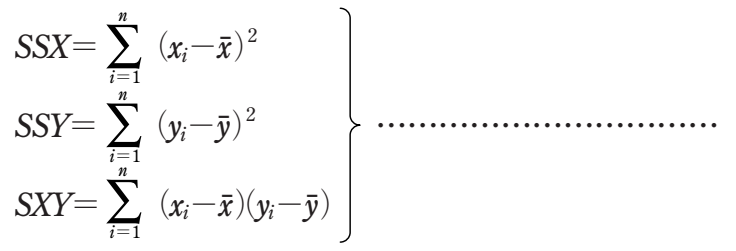

これから回帰直線の勾配 $M$ が式（5）のように求まる.

$$
M=\frac{S X Y}{S S X}
$$

この值を式（3）に入れると，各 $x_{i}$ に対するyの予測值 $\hat{y}_{i}$ が 求まるので，これから次式（6）のように回帰の残差平方和 SSRが得られる。

$$
S S R=\sum_{i=0}^{n}\left(y_{i}-\hat{y}_{i}\right)^{2}
$$

以上から，決定係数 $R^{2}$ ，一般誤差 $\varepsilon ，$ 勾配誤差 $\eta$ が求め られる。これらは，いずれも無名数である。快 $R^{2}$ 自由

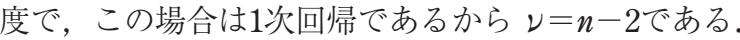

$$
\begin{aligned}
& R^{2}=\frac{S S Y-S S R}{S S Y}=1-\frac{S S R}{S S Y} \\
& \varepsilon=\sqrt{\frac{1}{\nu}\left(1-R^{2}\right)} \ldots \ldots \ldots \ldots \\
& \eta=\sqrt{\frac{1}{\nu}\left(\frac{1-R^{2}}{R^{2}}\right)}=\frac{\varepsilon}{|R|} \ldots . .
\end{aligned}
$$

なお式（4）の第2式と式（6）を比べると，yは一定值で あるが $\hat{y} は x$ に対応して変わるyの推定值であるから, 明らか 
にSSY>SSRであり, $R^{2}<1$ である。従って, 必然的に $\eta>\varepsilon$ である. なお, 式 (8) 根号内の $1-R^{2}$ は, 未決定係数とで も呼ぶべき值で，回帰により決定できなかった残差の割合 を表している。

$\eta$ は勾配 $M$ の分散から求めているが，その過程を参考の ため示しておくと以下のようである.

$$
\operatorname{Var}(M)=\frac{1}{S S X^{2}} \operatorname{Var}(S X Y)=\frac{\sum(x-\bar{x})^{2}}{S S X^{2}} \operatorname{Var}(y-\bar{y})=\frac{\sigma^{2}}{S S X}
$$

これを平方に開き $M$ に対する相対值で表すと，次のように なる。ただし次式への展開では， $\sigma^{2}$ の推定值として $S S R / \nu$ を用いている。この最終式中にある $S S X \cdot S S Y / S X Y^{2}$ は $1 / R^{2}$ と等しいから，その結果，式 (9) が導出される.

$$
\eta=\frac{S S X}{S X Y} \sqrt{\frac{\sigma^{2}}{S S X}}=\sqrt{\frac{1}{\nu} \cdot \frac{S S X \cdot S S R}{S X Y^{2}}}=\sqrt{\frac{1}{\nu} \cdot \frac{S S X \cdot S S Y\left(1-R^{2}\right)}{S X Y^{2}}}
$$

\subsection{3 非直線性}

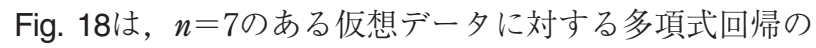
結果を示している.1次回帰では, 結果の直線に対し両端の データが上に, 中央のデータが下に外れていて，下に凸の 曲がりを示す系統的誤差がある。曲がりは2次回帰結果の破 線により表され，3次回帰結果の1点鎖線によりうねりが表 されている。

Fig. 19は，この仮想データについて，一般誤差 $\varepsilon$ 回帰 次数 $j$ 関係をみたもので，このデータでは3次のときに誤 差 の減少のため逆に誤差が増加している。

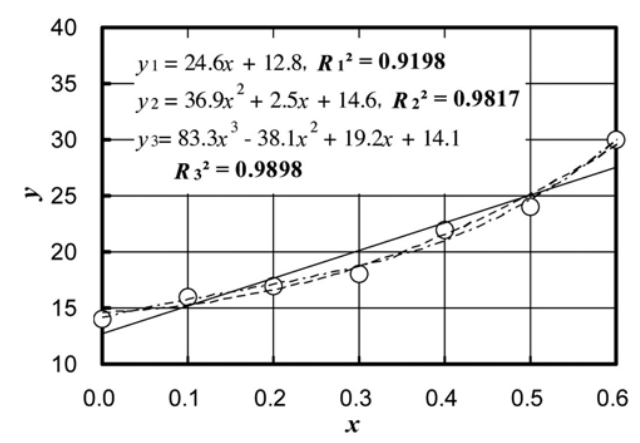

Fig. 18 Non-linearities for an imaginary data. Subscript in equations represent the order of polynomial regression analyses, with coefficient of determination $R^{2}$.

\section{1 .4 検討}

\subsubsection{1 回帰次数の決定}

多項式回帰の場合，回帰モデルの次数を上げることによ る誤差の改善が確率論的に有意かどうかは，次数を増すこ とによる残差平方和SSRの減少分に注目して，F検定により 判定することができる. Fig. 18の $R^{2}$ 值を元に分散分析表を 作ると，Table 10のようになる。 $R^{2}$ の下添え字は回帰式の 次数 $j$ 表す。

観測した分散比F $(j)$ は，例えば1次回帰の場合，回帰後 の分散はSSRを自由度で割った $\left(1-R_{1}^{2}\right) S S Y / 5 て ゙ ，$ 減少分 は $R_{1}^{2} S S Y$ ある。従って1次回帰による観測分散比 $F$ (1) と しては，後者の前者に対する比を考えればよい。ここでは 信頼水準 $95 \%$ として，F值の下側 $5 \%$ 点と比較して判定する. 他のケースも考えると, 以下のような各式が得られる.

$$
F(1)=\frac{5 R_{1}^{2}}{1-R_{1}^{2}}
$$

$$
\begin{aligned}
& F(2 \mid 1)=\frac{4\left(R_{2}^{2}-R_{1}^{2}\right)}{1-R_{2}^{2}} \\
& F(3 \mid 2)=\frac{3\left(R_{3}^{2}-R_{2}^{2}\right)}{1-R_{3}^{2}} \\
& F(3 \mid 1)=\frac{3\left(R_{3}^{2}-R_{1}^{2}\right)}{1-R_{3}^{2}}
\end{aligned}
$$

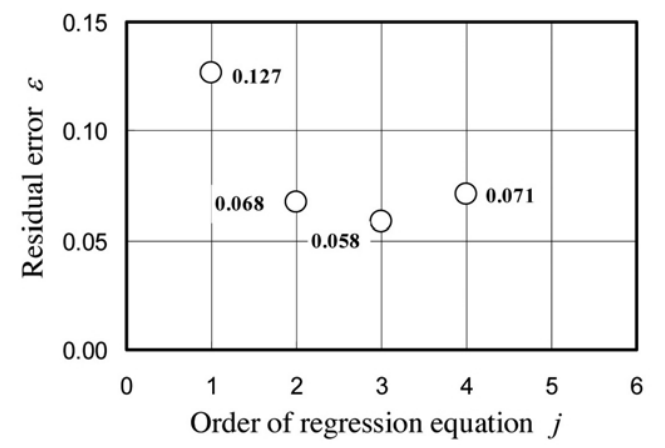

Fig. 19 Change in the residual error according to the order of regresssion polynomials in case of the imaginary data.

Table 10 Analysis of variance table for the improvement of residuals, SSR, by increasing the order of regression polynomials. Equations $\mathrm{F}(j)$ are to be found in the text.

\begin{tabular}{|c|c|c|c|c|c|c|c|}
\hline Order, $j$ & $\begin{array}{c}\text { Coefficient of } \\
\text { determination, } R^{2}\end{array}$ & $\begin{array}{c}\text { Residuals, } \\
S S R\end{array}$ & $\begin{array}{c}\text { Degree of freedom } \\
v\end{array}$ & $\begin{array}{c}\text { Improvement in } \\
S S R\end{array}$ & $\begin{array}{c}\text { Observed variance } \\
\text { ratio, } F(j)\end{array}$ & $5 \%$ point of $F$ & Judgement \\
\hline 1 & $R_{1}{ }^{2}=0.9198$ & $\left(1-R_{1}{ }^{2}\right) S S Y$ & 5 & $R_{1}{ }^{2} S S Y$ & $F(1)=57.35^{*}$ & $F_{1,5}=6.61$ & Significant \\
\hline 2 & $R_{2}{ }^{2}=0.9817$ & $\left(1-R_{2}{ }^{2}\right) S S Y$ & 4 & $\left(R_{2}{ }^{2}-R_{1}{ }^{2}\right) S S Y$ & $F(2 \mid 1)=13.52 *$ & $F_{1,4}=7.71$ & Significant \\
\hline 3 & $R_{3}{ }^{2}=0.9898$ & $\left(1-R_{3}{ }^{2}\right) S S Y$ & 3 & $\left(R_{3}{ }^{2}-R_{2}{ }^{2}\right) S S Y$ & $F(3 \mid 2)=2.37$ & $F_{1,3}=10.13$ & Not significant \\
\hline
\end{tabular}


ここでは次数を順次増加したときのSSRの減少分に着目 したが，これは例えば3次式に見られるうねりは，2次の放 物線上にのったものと捉えたことになるので，2次回帰後の 3次回帰結果として, 式 $(12)$ のように観測 $F$ 值は $F(3 \mid 2)$ と表記した。なお， $F(3 \mid 2)$ などの表記中，3|2は2を前提 とした 3 という意味で, 縦棒|の後に前提を示す一般的な表 現である。

これに対し $R_{1}{ }^{2}$ から $R_{2}{ }^{2}$ への改善が小さく, $F(2 \mid 1)$ が有意 とならない場合にも，うねりを1次の直線上にのったもの と捉えるとどうか，という問題もある。そのような場合に は，式（13）のように，直接 $F(3 \mid 1)$ を評価すればよい. なお式 $(10) \sim(13)$ は, いずれも測定悀数が7の場合であ るから，注意を要する。

Table 10によると，回帰は1次式については観測 $F$ 值の 57.35 に対しFの5\%点は6.61であるから強く有意であり， $x^{2}$ の項を追加して2次式にすることも有意と言えるが， $x^{3}$ の項 を追加することは有意とは言えないことがわかる.

なお，このような分析は4次以上の高次回帰についても可 能であるが，現時点でX線応力測定における誤差の検討に必 要とは考えにくいので，回帰モデルは1３次の範囲に留め ることが妥当である。

\subsubsection{2 曲がり度とうねり度}

前述の $F$ 検定を経て, 確率論的に有意と判定された曲がり やうねりについては，その程度を数量として表すことが望 まれる。例えばFig. 19のように，仮想データにおける当初

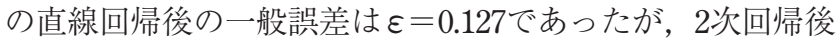
には0.068に減少している。この差が曲がりの寄与分である.

曲がりを考慮することによる決定係数の改善は，2次回帰 の決定係数 $R_{2}^{2}$ と 1 次回帰の決定係数 $R_{1}{ }^{2}$ の差を, 当初の未決 定係数 $1-R_{1}^{2}$ に対する比 $C_{B}$ として, 式（14）のように表す ことができる。これを曲がり度Bowingと呼ぶことにする。

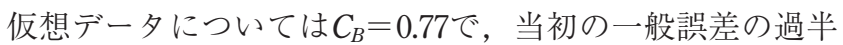
が曲がりによるものであったことがわかる。

$$
C_{B}=\frac{R_{2}^{2}-R_{1}^{2}}{1-R_{1}^{2}}
$$

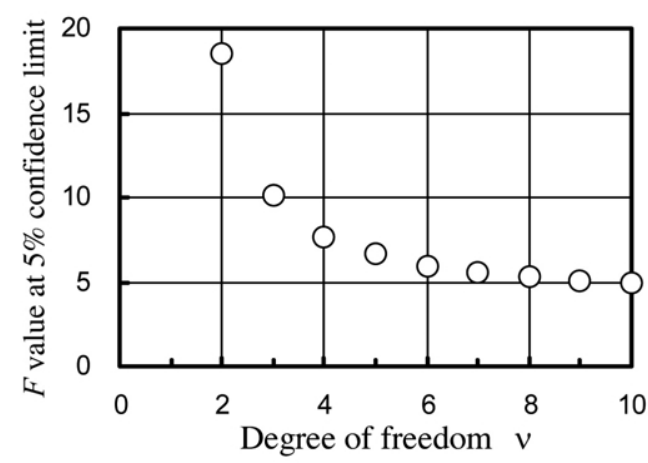

Fig. $20 \quad F$ value at 5\% confidence limit increases rapidly for smaller degrees of freedom. Suggesting at least 3 is needed to analyze the bowing $(n=6)$, and 4 to analyze the waving $(\mathrm{n}=7)$.
同様に, 2次から3次への次数増加による改善分 $C_{W \mid B}$ は, うねり度Wavingと呼ぶことができ，式（15）で表される。

$$
C_{W \mid B}=\frac{R_{3}^{2}-R_{2}^{2}}{1-R_{1}^{2}}
$$

仮想データについてはTable 10で有意でないと判定された が，事実 $C_{W \mid B}=0.10 て ゙$ 寄与は小さい。ただし式（15）では前 述のように，うねりを放物線に対し評価しているので，分 子は $R_{3}{ }^{2}-R_{2}{ }^{2}$ としている。詳細にいえば，評価量は曲がり (B) 除去後のうねり $(W)$ で，Cの下添え字 $W \mid B$ はそのこと を表している.

このように，この評価では次数増加による決定度の改善 分を1次から 2 次，2次から3次というょうに，いわば追加的 に考える。それは，確率論的に意味のない高次の解析を避 けるためである。しかし，技術的にはうねりを直線に対し 評価する必要も考えられる。そのときには，評価量 $C_{W L L}$ は 直線成分 $(L)$ 除去後のうねり $(W)$ であり，式（16）を用 いればよい.

$$
C_{W L}=\frac{R_{3}^{2}-R_{1}^{2}}{1-R_{1}^{2}}
$$

なお，うねりの中に曲がり成分があるかどうかは，グラ フの目視からでは判定が困難な場合がある．疑わしいとき には， $R_{2}^{2}$ と $R_{3}^{2}$ の双方について $F$ 検定を行うより仕方がない. ただし，データのn数不足などからそれができないときは， 低次数の解析にとどめておく方がよい。

\subsubsection{X線入射角の数及び曲がり, うねりの簡易判定 について}

Table 10 では，観測 $F$ 值を $F$ 分布の下側 $5 \%$ 点の值 $F_{0.05 ; 1, \nu}$ と

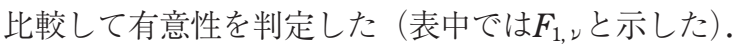

Fig. 20は，自由度レが小さくなると，判定基準とするF值

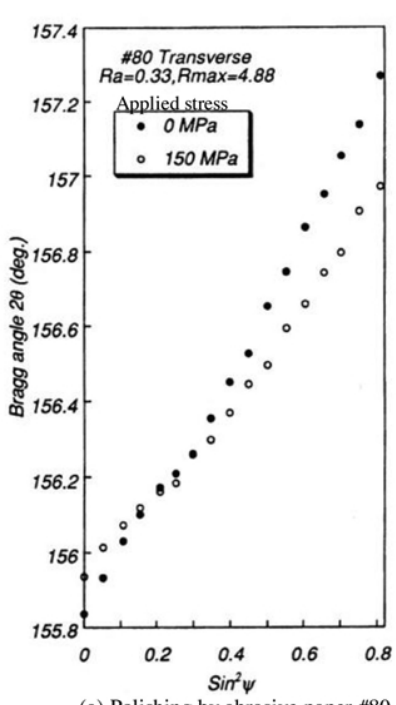

(a) Polishing by abrasive paper $\# 80$

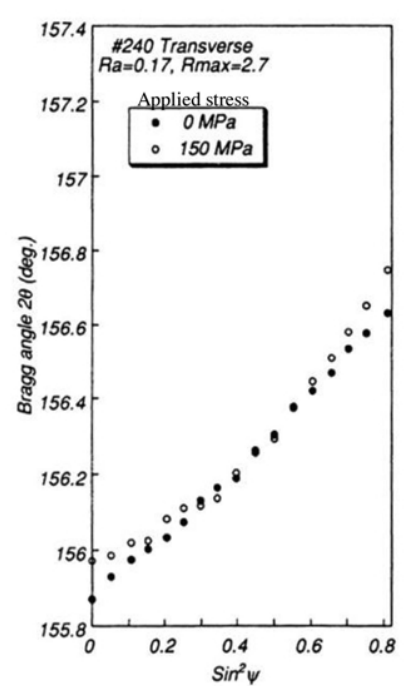

(b) Polishing by abrasive paper \#240
Fig. 21 Examples of $2 \theta-\sin ^{2} \psi$ diagrams having a bowing affected by the surface roughness due to abrasive paper polishing ${ }^{11)}$. 
が急激に大きくなることを示す。この值が大きいと，観測 $F$ 值が大きくても有意になりにくいから, 少なくともレ $\geq 3$ と すべきである。これは，うねりを評価できる3次回帰までを 考えるなら, X線入射角山の最小必要数として, 少なくとも $n \geq 7$ とすべきことを意味する。しかし曲がりを評価できれ

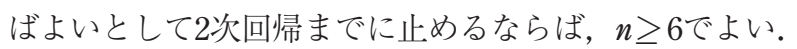

すなわち，うねりの評価までは行わない測定では，X線 入射角 $\psi$ の最小必要数は $n=6$ として十分であり, 曲がりの 評価も必要ない通常の測定では $n=5$ とするのが妥当と考え られる。

な执，Fig. 20は観測 $F$ 值が確率論的に有意かどうかの簡易 判定にも使用できる。つまり, 測定時の $n$ 数に対応する $F_{0.05}$ の概略值を Fig. 20から読んで扮き，それより明らかに小さ な観測 $F$ 值の場合は有意でないとして評価を打切ればよいの である。

\subsubsection{4 適用例}

Fig. 21は，4点曲げ試験片の表面をエメリー紙で研磨した

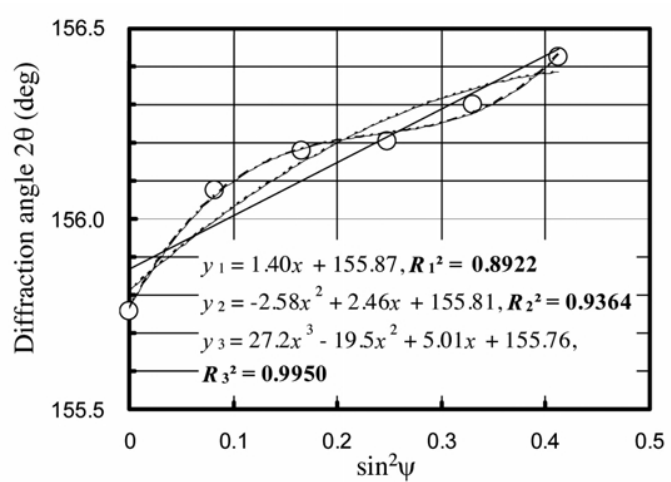

Fig. $222 \theta-\sin ^{2} \psi$ diagram for a spiral spring showing an intensive non-linearity (waving), offered by a member of the committee.
ことによる粗さの影響 11$) て ゙, ~ \sin ^{2} \psi$ 線図が湾曲している例で ある。この場合，研磨の方向は主応力に直角で，したがっ て角の傾斜方向に対して直角である。また，うねりを持つ データの例として, Fig. 22は渦巻ばねの測定結果, Fig. 23 はトーションバーの測定結果の一例である。この二例は, いずれも当委員会の有志委員からデー夕の提供を受けた。

Figs. 21〜23のデー夕について, 解析結果をTable 11にま とめた. $F$ の $5 \%$ 点の数值は, それぞれ $n=17,6,5$ に対し, 2次回帰では4.60，10.13，18.51，3次回帰では4.68，18.51, 161.45であるが，前述のように $n=5$ で2次，3次の回帰を考 えることには無理がある。そのような観測 $F$ 值は，カッコつ きで参考として示しておいた。

ペーパ研磨データには，いずれも有意な曲がりがあるが， うねりは $C_{W I B}$ が小さいことから問題にならない。渦巻きば ねには，曲がりは有意ではなく，直線にのったうねり $C_{W L}$

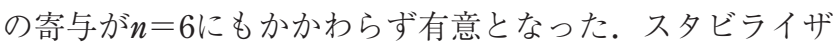
については3つの測定例があり, 三例とも軽度の曲がりがあ

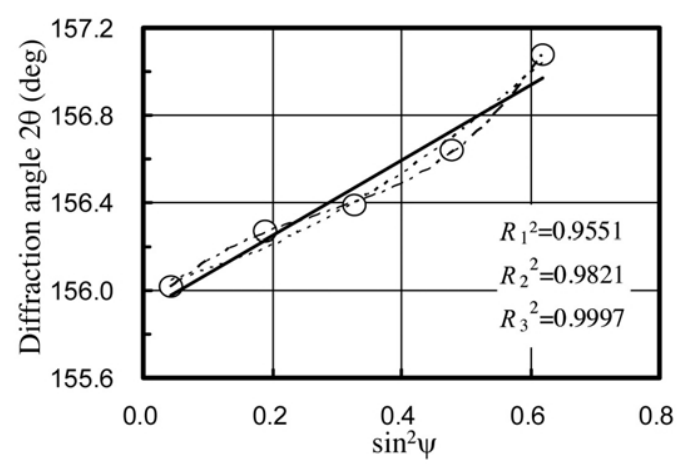

Fig. $232 \theta-\sin ^{2} \psi$ diagram for a stabilizer showing a nonlinearity (waving), offered by a member of the committee.

Table 11 Analytical results of the data in Figs. 21, 22, and 23.

\begin{tabular}{|c|c|c|c|c|c|c|c|c|c|}
\hline & \multicolumn{2}{|c|}{ Abrasive paper \#80 } & \multicolumn{2}{|c|}{ Abrasive paper $\# 240$} & \multirow{2}{*}{$\begin{array}{l}\begin{array}{l}\text { Spiral } \\
\text { spring }\end{array} \\
\end{array}$} & \multirow{2}{*}{$\begin{array}{c}\text { Stabilizer } \\
1\end{array}$} & \multirow{2}{*}{$\begin{array}{l}\text { Stabilizer } \\
2\end{array}$} & \multirow{2}{*}{$\begin{array}{c}\text { Stabilizer } \\
3\end{array}$} & \multirow{2}{*}{$\begin{array}{c}\text { Committee } \\
\text { 1st RRT }\end{array}$} \\
\hline & $0 \mathrm{MPa}$ & $150 \mathrm{MPa}$ & $0 \mathrm{MPa}$ & $150 \mathrm{MPa}$ & & & & & \\
\hline Sample size, $n$ & 17 & 17 & 17 & 17 & 6 & 5 & 5 & 5 & 5 \\
\hline Slope, $M$ & 1.742 & 1.259 & 0.956 & 0.951 & 1.397 & 1.725 & 1.801 & 3.176 & 1.661 \\
\hline Coeff. determ., $R_{1}{ }^{2}$ & 0.9908 & 0.9858 & 0.9913 & 0.9523 & 0.8922 & 0.9551 & 0.9733 & 0.9838 & 0.9983 \\
\hline Coeff. determ., $R_{2}^{2}$ & 0.9975 & 0.9966 & 0.9961 & 0.9968 & 0.9364 & 0.9821 & 0.9858 & 0.9921 & 0.9995 \\
\hline Coeff. determ., $R_{3}{ }^{2}$ & 0.9976 & 0.9969 & 0.9966 & 0.9970 & 0.9950 & 0.9997 & 0.9964 & 0.9957 & 0.9996 \\
\hline Residual error, $\varepsilon$ & 0.025 & 0.031 & 0.024 & 0.056 & 0.164 & 0.122 & 0.094 & 0.073 & 0.024 \\
\hline Slope uncertainty, $\eta$ & 0.025 & 0.031 & 0.024 & 0.058 & 0.174 & 0.125 & 0.096 & 0.074 & 0.024 \\
\hline Observed $F(2 \mid 1)$ & $37.52 *$ & $44.47 *$ & $17.23^{*}$ & $194.69^{*}$ & 2.08 & 3.02 & 1.76 & 2.10 & 4.80 \\
\hline Observed $F(3 \mid 2)$ & 0.54 & 1.26 & 1.91 & 0.87 & $23.44^{*}$ & 58.67 & 2.94 & 0.84 & 0.25 \\
\hline Observed $F(3 \mid 1)$ & $(36.83)$ & $(46.55)$ & $(20.26)$ & (193.70) & 41.12 & 148.67 & 6.42 & 2.77 & 3.25 \\
\hline Bowing, $C_{B}$ & 0.73 & 0.76 & 0.55 & 0.93 & $(0.41)$ & $(0.60)$ & $(0.47)$ & $(0.51)$ & $(0.71)$ \\
\hline Waving on $\mathrm{B}, C_{W \backslash B}$ & 0.01 & 0.02 & 0.06 & 0.00 & 0.54 & $(0.39)$ & $(0.40)$ & $(0.22)$ & $(0.06)$ \\
\hline Waving on $\mathrm{L}, C_{W L}$ & $(0.74)$ & $(0.78)$ & $(0.61)$ & $(0.94)$ & 0.95 & $(0.99)$ & $(0.87)$ & $(0.73)$ & $(0.76)$ \\
\hline
\end{tabular}

Note: Values with * are significant on $95 \%$ confidence basis, where $F(2 \mid 1)$ indicates the bowing on straight line and $F(3 \mid 2)$ the waving on parabolic line. The stabilizer 1 seems to have a waving on strait line, $F(3 \mid 1)$, but not counted for a lack of sample size. 
るが，有意とは言えず，うねりは自由度不足のため評価で きない. Table 11には本委員会RRTによる例も示したが，曲 がりは有意とはいえない。これらはいずれも $n=5$ としてい るため, 検出力が十分でなかった結果かも知れない.

また全体として，一般誤差は勾配誤差より少し小さいが ほほ同等の值で，それは式（7）からも自明である。

以上の検討結果を総合すると, $\sin ^{2} \psi$ 線図に有意な曲がり やうねりがあるかどうかを判定するために，回帰による決 定係数 $R^{2}$ を参照することが十分有効と考えられる。特に有 意な曲がりがない場合にも，うねりに関しては有意となるこ とがあるので，デー夕は必ずグラフに示すなど，解析には 注意が必要である。さらに，本論文で述べたような曲がり を数量化するためには，X線入射角山は少なくとも6点以上， うねりを検討するためには7点以上とすることが望ましい。

\subsection{5 $\sin ^{2} \psi$ 線図における非直線度評価法の提案}

$\sin ^{2} \psi$ 線図上の回帰直線の不確かさを分析する量の一つと して，曲がりやうねりの評価を行うことを提案した。今回 の提案は多項式の回帰モデルを用い, 不確かさは決定係数 $R^{2}$ に基づく相対值としているので，比較評価に便利である.

結論としてX線応力評価における不確かさとしては, 次 の諸量を用いるのがよいと考えられる。これらはいずれも 相対值として無次元の数值または\%で表示するのがよい.

（1）一般誤差：回帰直線全体の不確かさ

式 (8)

(2) 勾配誤差：回帰直線の勾配の不確かさ

(3) 曲がり度：一般誤差に占める曲がりの割合

（4）曲がり除去後のうねり度： 式（15）

(5)直線に対するうねり度：

なお，X線応力測定における解の数としては，回帰直線 の曲がりを検出するためには少なくとも6点，うねりを含め て検出するためには7点以上が望ましいと考えられる。ただ しこの数は，対象物の初回測定などにおいて，その特性や 調製プロセス等について検討するなどの目的で，詳細分析 を行う場合に考える数である。品質管理などの目的で行う

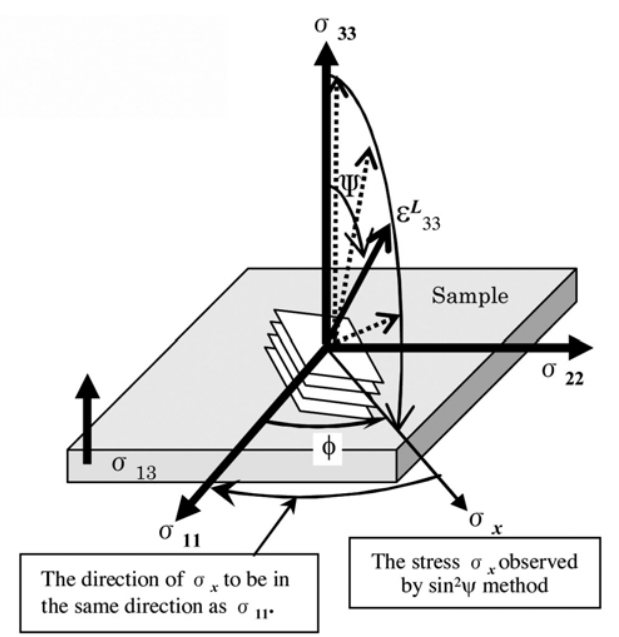

Fig. 24 The measurement direction of residual stress $\sigma_{x}$ observed by the $\sin ^{2} \psi$ method in the tri-axial stress state.
通常の測定では，工業測定における費用対効果などの観点 から，別途定めることは何ら差し支えない。

$5.2 \sin ^{2} \psi$ 線図における非直線度のシミュレーション的検討

一般的に, X線侵入深さ内に深さ方向のせん断応力が存在 すると $\sin ^{2} \psi$ 線図に曲がりが現れる。また，深さ方向の $\sigma_{33}$ 成 分 (静水圧成分) に応力勾配が存在する場合はうねりが現 れる。そこで，本節では意図的に既知の応力テンソルを設 定して得られる $\sin ^{2} \psi$ 線図をシミュレーションで作成し，曲 がり度,うねり度の評価を試みた。さらにどの程度の曲がり 度 $C_{B}$ とうねり度 $C_{W L}$ ならば $\sin ^{2} \psi$ 法で応力を算出しても問題 はないかどうかについて検討した。

5.2.1 三軸応力状態における $\sin ^{2} \psi$ 線図のシミュレーション 試料にせん断応力と深さ方向の応力勾配が存在すること を仮定して，シミュレーションで曲がりそしてjねりを有 する $\sin ^{2} \psi$ 線図を作成した。

Fig. 24に示すように試料に対して三軸応力を仮定する. 三軸応力の座標は, 試料側面に平行になるように試料表面 内に $\sigma_{11}$ と $\sigma_{22}$ をとり, 試料面法線方向に $\sigma_{33}$ をとる.

また深さ方向のせん断応力 $\sigma_{13}$ の向きは $\sigma_{11}$ に垂直な面に沿 って $\sigma_{33}$ 方向になる。なお，本シミュレーションでは $\sin ^{2} \psi$ 法 により測定される応力 $\sigma_{x}$ の向きを $\sigma_{11}$ 方向に取ることにす る。試料としてはフェライト系鉄鋼 $(\alpha \mathrm{Fe})$ を設定した。 そして, Fig. 24に示した応力座標系で, 既知の応力テンソ ルを設定し，a）三軸応力状態における深さ方向に一定のせ ん断応力 $\sigma_{13}$ を有する場合と, b) 深さ方向の $\sigma_{33}$ 成分の応力 勾配を有する場合の 2 種類の $\sin ^{2} \psi$ 線図をシミュレーションす ることにより求めた ${ }^{12)}$.

せん断応力が存在する試料に対する応力モデルについて は， $\sin ^{2} \psi$ 線図に廿スプリットが生じる場合の曲がり度の評 価を行った。

つぎに，深さ方向の応力勾配 ${ }^{13) ， 14)}$ を有する $\sin ^{2} \psi$ 線図の

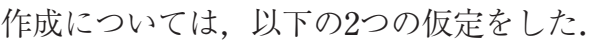

1）試料表面から最大 $X$ 線侵入深さ $\tau_{\text {max }}$ までの垂直応力成分 $\sigma_{33}$ を, 表面を $0 \mathrm{MPa}$ として深さに比例して階層的に圧縮 残留応力が増加していく.ただし, 最大X線侵入深さと は, Fig. 25に示すようにX線の入射角 $\alpha$ と出射角 $\beta$ が等し く，X線強度が1/eになる深さをいう。

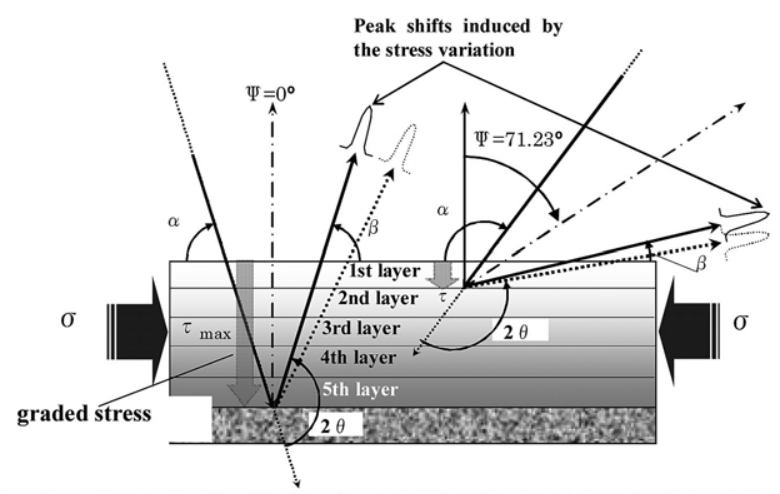

Fig. 25 The peak shifts of X-ray diffractions in a specimen with the stress variation along the depth direction. 
2) $\sin ^{2} \psi$ 法の各廿角で入射するX線はそれぞれのX線侵入深さ の層に達してから回折し, X線が通過する途中の層から は回折しない。

深さ方向に応力勾配が存在する試料に対する応力モデル では，Fig. 25に示したようにX線が入射する悀に依存して X線侵入深さてが決まる。

式（17）はX線の入射角を $\alpha$, 出射角を $\beta$, 試料の線吸収

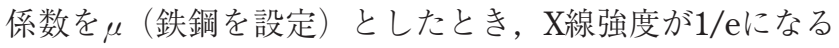
深さてを示している。

$$
\tau=\frac{1}{\mu} /\left(\frac{1}{\sin \alpha}+\frac{1}{\sin \beta}\right)
$$

ここで測定する反射のブラッグ角を $\theta$ とすると, 最大X線 侵入深さ $\tau_{\text {max }}$ は $\alpha=\beta=\theta$ を式（17）に代入して， $\tau_{\max }=\sin$ $\theta /(2 \mu)$ と表わされる.

本シミュレーションでは, 深さ方向の応力 $\sigma_{33}$ にいて, X線の最大侵入深さ $\tau_{\max }$ を 5 等分することにより, 試料表面 の応力を $\sigma_{330}=0 \mathrm{MPa}$, 第 $i(i=1 \sim 5)$ 層に残留する応力を $\sigma_{33 i}=i / 5 \cdot \sigma_{\max }$ とする。ここで, $\sigma_{\max }$ はX線の最大侵入深さ の層に残留する応力である.

本シミュレーションにより作成 ${ }^{15)} し た \sin ^{2} \psi$ 線図に対して 非直線度の要因の一つであるうねり度の評価に使用した。

\section{2 .2 単軸応力 $\sigma_{11}$ にせん断応力 $\sigma_{13}$ が存在する $\sin ^{2} \psi$ 線 図における曲がり度の評価}

作成した $\sin ^{2} \psi$ 線図は， $\sigma_{11}$ を $-500 \mathrm{MPa}$ とし，せん断応力 $\sigma_{13}$ は5段階の応力 $(10 \mathrm{MPa}, 20 \mathrm{MPa}, 30 \mathrm{MPa}, 40 \mathrm{MPa}$, $50 \mathrm{MPa}$ をを設定した。 5段階の応力状態に対して, $\sin ^{2} \psi$ 法に よって算出される応力 $\sigma_{x}$ を求めた.

$\sigma_{13}$ が $20 \mathrm{MPa}$ と $50 \mathrm{MPa}$ のとの $\sin ^{2} \psi$ 線図の一例を Fig. 26 に示す。解析結果から, $\sin ^{2} \psi$ 法による算出応力 $\sigma_{x}$ は, $\sigma_{13}$ が $20 \mathrm{MPa}$ の場合, $\sigma_{x}=-468 \mathrm{MPa}$ で $\sin ^{2} \psi$ 線図の曲がり度は $C_{B}=0.843$ である。 $\sigma_{13}$ が50MPaの場合は $\sigma_{x}=-417 \mathrm{MPa}$, 曲 がり度 $C_{B}=0.818$ となった。他の解析結果も考慮すると, 試 料に与えた既知の応力 $\sigma_{11}=-500 \mathrm{MPa}$ に対して $\sin ^{2} \psi$ 法によ る応力 $\sigma_{x}$ が $5 \%$ 以下の誤差となるのは $\sigma_{13}$ が $20 \mathrm{MPa}$ 以下にな

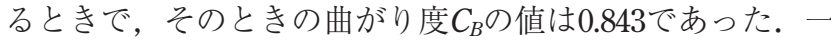
方， $\sigma_{13}$ が50MPaのときに $\sin ^{2} \psi$ 法による応力 $\sigma_{x}$ の誤差は $17 \%$ になりとても無視できるような誤差ではなかった.

$\sigma_{11}=-500 \mathrm{MPa}$ ときの一例ではあるが，曲がり度 $C_{B}$ が 0.843 以上であれば，あえて複雑かつ時間を要する三軸 $\mathrm{X}$ 線 応力解析を行わなくても実用上問題ないと判断できる.

しかし，本シミュレーションでは $\sigma_{11}$ を $-500 \mathrm{MPa} と し て$ 種々のせん断応力 $\sigma_{13}$ を設定したのみであり， $\sigma_{11}$ を他の值 に設定したときに必ずしも「曲がり度 $C_{B}$ が 0.843 以上であれ ば $\sin ^{2} \psi$ 法による応力值が実際の值の $95 \%$ 以上となる」とは結 論できない.

\subsection{3 単軸応力 $\sigma_{11}$ に深さ方向の $\sigma_{33}$ 応力勾配が存在する $\sin ^{2} \psi$ 線図におけるうねり度の評価}

試料に対して深さ方向 $\left(\sigma_{33}\right)$ に応力勾配が存在すること を仮定し， $\sigma_{11}$ にー300MPaの圧縮応力を与えた。また，応 力勾配は試料表面で $0 \mathrm{MPa}$ ，最大X線侵入深さで $\sigma_{33 \max }=$ $-50 \mathrm{MPa},-100 \mathrm{MPa},-150 \mathrm{MPa},-180 \mathrm{MPa},-200 \mathrm{MPa}$ の5段階の圧縮応力を設定した。 $\sigma_{33}$ の応力勾配が $\sigma_{33 \max }=$ $-150 \mathrm{MPa}(0 \sim 150 \mathrm{MPa}), \sigma_{33 \max }=-200 \mathrm{MPa} \quad(0 \sim 200 \mathrm{MPa})$ 時に得られた $\sin ^{2} \psi$ 線図の一例をFig. 27に示す.

まず， $\sigma_{33}$ の応力勾配を $\left|\sigma_{33 \max }\right|=150 \mathrm{MPa}$ としたときに， $\sin ^{2} \psi$ 法による算出応力は $\sigma_{x}=-273 \mathrm{MPa}$ ，そのときのうね り度 $C_{W \mid L}=0.486$ あった。 $\left|\sigma_{33 \max }\right|=200 \mathrm{MPa}$ の場合は $\sigma_{x}=$ - 264MPaで，そのときのうねり度 $C_{W \mid L}=0.485$ となった。結 果として見掛けは $\sin ^{2} \psi$ 法による測定結果が実際の值の $95 \%$ 以上になるのはうねり度 $C_{W I L}$ が 0.486 以上のときであるとい う結論ではあるが, $\left|\sigma_{33 \max }\right|=200 \mathrm{MPa}$ の場合のうねり度 $C_{W \mid L}=0.485$ との明確な有意差の確認はできないと判断して いる。うねり度 $C_{W L L}$ を基準として $\sin ^{2} \psi$ 法の適用が可能か否 かは，今後うねり度が大きくなるような多くの応力テンソ ルに対しての解析を蓄積した上で結論を得たい.

\subsection{4 $\sin ^{2} \psi$ 線図における非直線度のシミュレーション 的検討のまとめ}

三軸応力状態において既知のせん断応力あるいは深さ方 向に応力勾配が存在する試料を仮定して，シミュレーショ
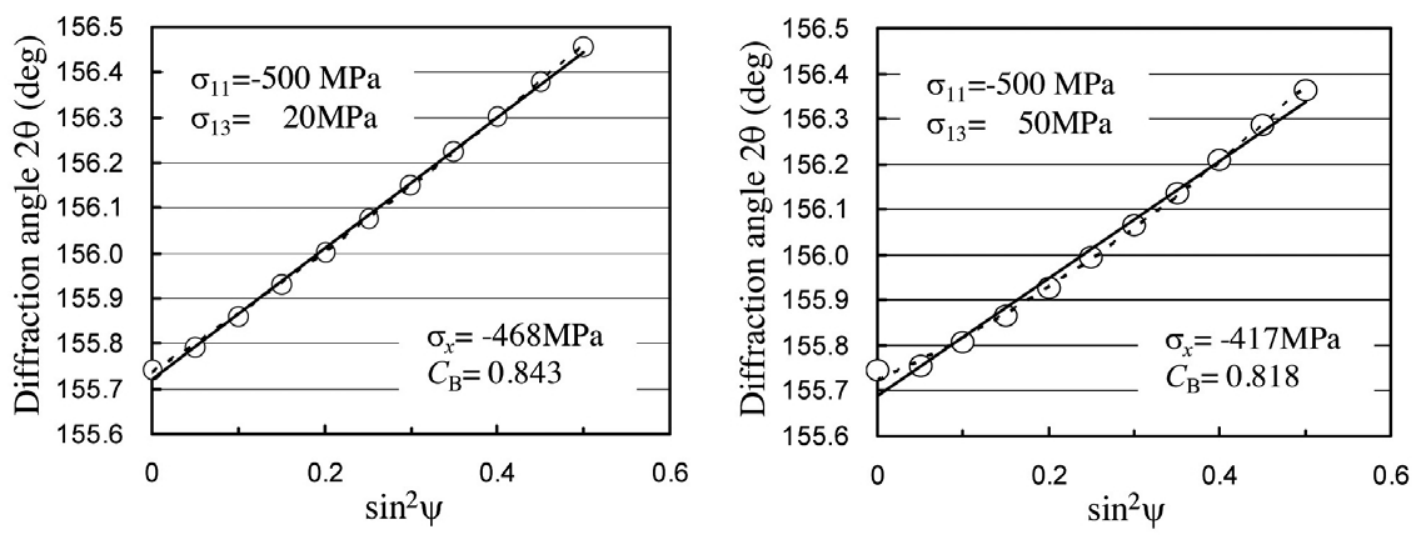

(a) $\sigma_{11}=-500 \mathrm{MPa}$ with $\sigma_{13}=20 \mathrm{MPa}$

(b) $\sigma_{11}=-500 \mathrm{MPa}$ with $\sigma_{13}=50 \mathrm{MPa}$.

Fig. $262 \theta-\sin ^{2} \psi$ diagrams (the simulation of bowing). 


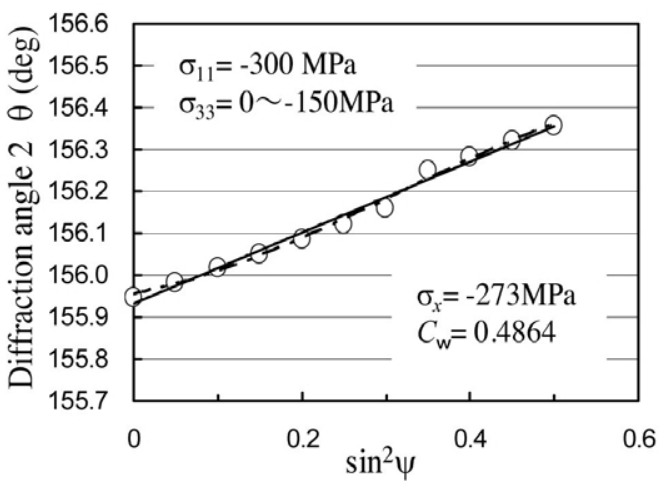

(a) $\sigma_{11}=-300 \mathrm{MPa}$ and $\sigma_{33}=0 \sim-150 \mathrm{MPa}$.

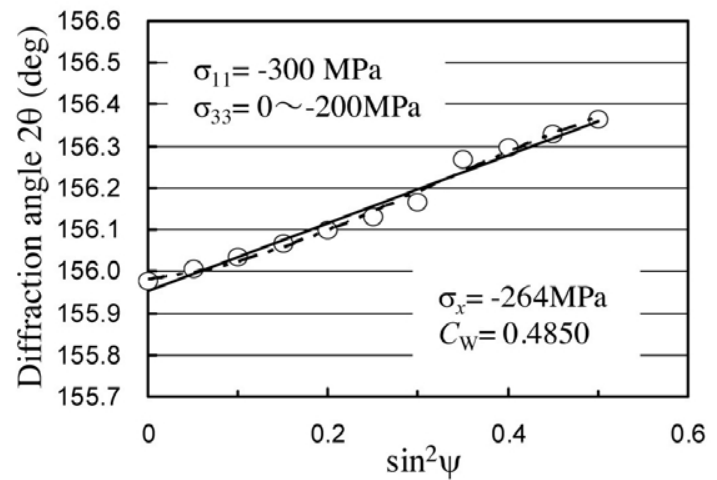

(b) $\sigma_{11}=-300 \mathrm{MPa}$ and $\sigma_{33}=0 \sim-200 \mathrm{MPa}$.

Fig. $272 \theta-\sin ^{2} \psi$ diagrams (the simulation of waving).

ンにより $\sin ^{2} \psi$ 線図を作成した。作成した線図に対して， $\sin ^{2} \psi$ 法により算出した応力と非直線度（曲がり度及びうね り度）の関係を検討することを試みた。

結果として， $\sin ^{2} \psi$ 線図の非直線度を数值的に評価する手 法の手掛かりが得られた。今までほとんど評価されること がなかった $\sin ^{2} \psi$ 線図の非直線度による評価方法の試みで, $\sin ^{2} \psi$ 法が適用できる限界を曲がり度,うねり度の臨界值で提 示できる可能性は十分ある。しかし, 現状では, 応力モデ ルの設定数が少なく, かつ単軸応力 $\sigma_{11}$ の系統だった応力值 設定が充分ではなかった.

今後はさらに多くの応力モデルを仮定して同じシミュレ ーション手法で $\sin ^{2} \psi$ 線図を作成し，その曲がり度及びうね り度を評価すると同時に，実際の試料を用いて実験的な検 証も行う必要がある。今後の課題としたい.

\section{6. ばね鋼のX線応力定数}

X線による残留応力測定を正確に行うためには，測定対 象材料のX線応力定数を正しく知ることが重要となる.

フェライト系ばね鋼の測定には2章のアンケート結果が示 すとおり，約70\%の企業が日本材料学会「X線応力測定法標 準」1) での推奨值であるX線応力定数 $K=-318 \mathrm{MPa} / \mathrm{deg}$ とい う值を使用しているのが現状である。

このX線応力定数 $K=-318 \mathrm{MPa} / \mathrm{deg}(\mathrm{X}$ 線的弾性定数 $E$ / $(1+\nu)=175 \mathrm{GPa})$ の值がどのように求められたかを調べる と, X線材料強度部門委員会 (応力測定と弾性分科会) にお ける共同研究の結果 ${ }^{16)}$ から得られた值である。その詳細は, 試験片として，結晶粒度の異なる純鉄，中炭素鋼（S45C） の焼ならし材，焼入れ焼戻し材及び共析鋼（C=0.78\%）の 焼ならし材を用いてX線的弾性定数 $E /(1+\nu)$ を共同研究で 実測し，測定されたすべての鋼種・組織における平均值と して求められた值である。したがってX線応力定数 $K=-$ $318 \mathrm{MPa} / \operatorname{deg}$ の值は必ずしもばね鋼に適しているとは限らな い.さらに，ばねの設計や有限要素法などによるばねの強 度評価を行う上にはショットピーニングにより導入された 圧縮残留応力の絶対值が必要になる。

そこで, 本委員会としてはX線応力定数の測定方法を確 認するとともに，一般的なフェライト系ばね鋼のX線応力定
数の参考值を提案するため, X線応力定数測定のラウンドロ ビン試験（第3回RRT）を行った。 RRTは2鋼種各2個のサン プルを作製し，2系統12機関にて実施した。

\section{1 供試材及び試験片}

供試材には，SUP12及びSUP9Aを使用した。試験片は4点 曲げ試験を行うために平板とした。作製方法は，まず供試 材を短冊状に切削加工し, $850^{\circ} \mathrm{C} \times 20 \mathrm{~min}$ 加熱後油焼入れを 行い, SUP9Aは $410^{\circ} \mathrm{C} \times 1 \mathrm{~h}, \mathrm{SUP} 12$ は $440^{\circ} \mathrm{C} \times 1 \mathrm{~h}$ で焼戻しを 行い，その後研削加工した。試験片寸法は，SUP9Aは幅 $B$ $30 \mathrm{~mm} \times$ 長さ $L 126 \mathrm{~mm} \times$ 板厚 $t 3 \mathrm{~mm}$ ，SUP12は幅 $B 9 \mathrm{~mm} \times$ 長 さ $L 129 \mathrm{~mm} \times$ 板厚 $t 3 \mathrm{~mm}$ である.

最後に測定表面の研削加工の影響を除去するため電解研 磨を行った。電解研磨領域は試験片中央部 $\square 10 \mathrm{~mm}$ とした が, SUP9Aでは幅30mmなので部分研磨，SUP12は幅9mmな ので幅方向全面研磨とした。供試試験片をTable 12に示す。

\subsection{X線応力定数の測定方法}

$\sin ^{2} \psi$ 法によるX線応力測定法の原理を以下に示す。

多結晶に波長入の特性X線を照射した際に回折を生じる条 件は，式（18）のBraggの回折式で表される。ただしdは回 折面間隔及び $\theta$ はBragg角である。

$2 d \sin \theta=\mathrm{n} \lambda$

入を定数として式 (18) を全微分すると次式のようになる.

$$
\begin{aligned}
& 2 \sin \theta \frac{\Delta d}{\Delta \theta}+2 d \cos \theta=0 \\
& \frac{\Delta d}{d}=-\cot \theta \cdot \Delta \theta
\end{aligned}
$$

Fig. 28に試験片，測定される応力 $\sigma_{x}$ とひずみ $\varepsilon_{\psi}$ の座標系 を示す。回折面の法線方向のひずみ $\varepsilon_{\psi}$ は式（19）より式 （20）で近似的に表される.

$$
\varepsilon_{\psi}=\frac{d_{\psi}-d_{0}}{d_{0}}=-\cot \theta_{0} \cdot \Delta \theta=-\frac{\cot \theta_{0}}{2}\left(2 \theta_{\psi}-2 \theta_{0}\right) \ldots \ldots
$$

ここで $\theta_{0}, 2 \theta_{0}$ は無ひずみ状態のBragg角及び回折角で，2 $\theta_{\psi}$ は応力負荷時の回折角である.

また，平面応力状態を仮定したX線応力測定法の基本式 
Table 12 Dimensions and characteristics of specimen to determine X-ray stress constant.

\begin{tabular}{|c|c|c|c|c|c|c|c|}
\hline Steel & No. & $\begin{array}{c}\text { Thickness } \\
t(\mathrm{~mm})\end{array}$ & $\begin{array}{l}\text { Width } \\
B(\mathrm{~mm})\end{array}$ & $\begin{array}{l}\text { Length } \\
L(\mathrm{~mm})\end{array}$ & $\begin{array}{c}\text { Depth of } \\
\text { electro polishing } \\
d(\mathrm{~mm})\end{array}$ & Hardness & $\begin{array}{c}\text { Grain } \\
\text { size }\end{array}$ \\
\hline \multirow{2}{*}{ SUP9A } & 1 & 2.66 & 30.02 & 126.4 & 0.15 & \multirow{2}{*}{ HV 510} & \multirow{2}{*}{ No.9.3 } \\
\hline & 2 & 2.66 & 29.17 & 126.4 & 0.11 & & \\
\hline \multirow{2}{*}{ SUP12 } & 1 & 3.04 & 9.01 & 129.3 & 0.06 & \multirow{2}{*}{ HV 515} & \multirow{2}{*}{ No.8.1 } \\
\hline & 2 & 3.04 & 9.04 & 129.1 & 0.13 & & \\
\hline
\end{tabular}

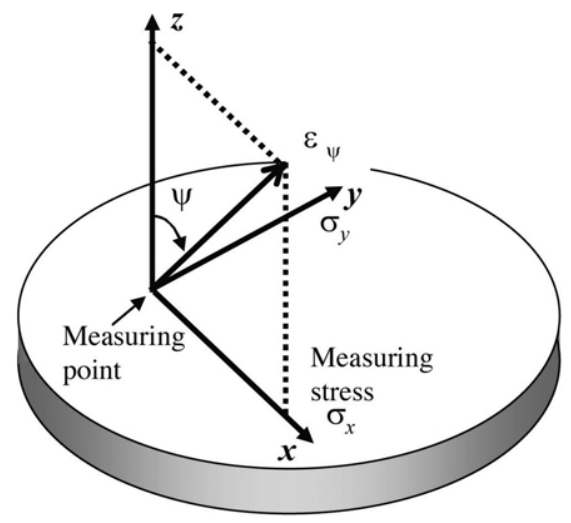

Fig. 28 Coordinate system of stresses and strains.

は式（21）で表される。なお式中のEは縦弾性係数（ヤング 率), レはポアソン比である。

$$
\varepsilon_{\psi}=\frac{1+\nu}{E} \sigma_{x} \sin ^{2} \psi-\frac{\nu}{E}\left(\sigma_{x}+\sigma_{y}\right)=\frac{\mathrm{S}_{2}}{2} \sigma_{x} \sin ^{2} \psi+\mathrm{S}_{1}\left(\sigma_{x}+\sigma_{y}\right)
$$

ここで $S_{1}, S_{2}$ はX線的コンプライアンスと呼ばれ，式 $(22)$ で表される。

$$
S_{2}=\frac{2(1+\nu)}{E}, S_{1}=-\frac{\nu}{E}
$$

式（20）に式（21）を代入し，整理すると次式のように なる。

$$
\begin{aligned}
& -\frac{\cot \theta}{2}\left(2 \theta_{\psi}-2 \theta_{0}\right)=\frac{S_{2}}{2} \sigma_{x} \sin ^{2} \psi+S_{1}\left(\sigma_{x}+\sigma_{y}\right) \\
& 2 \theta_{\psi}=-\frac{S_{2}}{\cot \theta_{0}} \sigma_{x} \sin ^{2} \psi-\frac{2 S_{1}}{\cot \theta_{0}}\left(\sigma_{x}+\sigma_{y}\right)+2 \theta_{0}
\end{aligned}
$$

式（23）を $\sin ^{2} \psi て ゙$ 偏微分すると次式のようになる.

$$
\begin{aligned}
& \frac{\partial 2 \theta_{\psi}}{\partial \sin ^{2} \psi}=-\frac{S_{2}}{\cot \theta_{0}} \sigma_{x} \\
& \sigma_{x}=-\frac{\cot \theta_{0}}{S_{2}} \frac{\partial 2 \theta_{\psi}}{\partial \sin ^{2} \psi}=K \frac{\partial 2 \theta_{\psi}}{\partial \sin ^{2} \psi}
\end{aligned}
$$

ここでKをX線応力定数と呼び，式（25）で表される.

$$
K=-\frac{\cot \theta_{0}}{S_{2}}[\mathrm{MPa} / \mathrm{rad}]=-\frac{\cot \theta_{0} \cdot E}{2(1+\nu)} \frac{\pi}{180}[\mathrm{MPa} / \mathrm{deg}]
$$

以上がX線応力測定法の原理である.
次にX線応力定数 $K$ の測定法について述べる. X線応力定 数Kを求めるためには, 単軸の付加荷重を試験片に加えるこ とが望ましく，そのとき $\sigma_{x}=\sigma_{1}, \sigma_{y}=\sigma_{2}=0 （ \sigma_{1}, \sigma_{2}$ は主 応力）の応力状態となり， $\sigma_{x}$ は残留応力 $\sigma_{\text {res }}$ と付加応力 $\sigma_{\mathrm{A}}$ の和となる。

この状態を式 (24) に当てはめると次式のようになる.

$$
\sigma_{x}=\sigma_{\mathrm{res}}+\sigma_{\mathrm{A}}=K \frac{\partial 2 \theta_{\psi}}{\partial \sin ^{2} \psi}
$$

式 $(26)$ を $\sigma_{\mathrm{A}}$ で偏微分すると残留応力 $\sigma_{\mathrm{res}}$ は一定である ので式 (27) となる.

$$
\frac{1}{K}=\frac{\partial\left(\frac{\partial 2 \theta_{\psi}}{\partial \sin ^{2} \psi}\right)}{\partial \sigma_{\mathrm{A}}}=\frac{\partial M}{\partial \sigma_{\mathrm{A}}}
$$

ここで $M$ は付加応力 $\sigma_{\mathrm{A}}$ を加えたときの $\sin ^{2} \psi$ 線図の傾きで ある。

X線応力定数測定の第3回RRTは式（27）に基づいて行っ た。測定の要領はつぎの通りである。

（1）試験片に既知の付加応力 $\sigma_{\mathrm{A}}$ を与える.このとき付加応 力 $\sigma_{\mathrm{A}}$ は付加方式に応じて試験片形状 · 寸法と付加荷重か ら算出した值で既知である。つぎに種々の付加応力 $\sigma_{\mathrm{A}}(\mathrm{MPa})$ の下で $\sin ^{2} \psi$ 線図の測定を行い, それぞれの線 困の傾き $M(\mathrm{deg})=\partial 2 \theta / \partial \sin ^{2} \psi$ を求める.

(2) 傾き $M(\mathrm{deg})$ - 付加応力 $\sigma_{\mathrm{A}}(\mathrm{MPa})$ 線図を作成し，その 線図の勾配 $\partial M / \partial \sigma_{\mathrm{A}}(\mathrm{deg} / \mathrm{MPa})$ を直線回帰で求める. 得られた值の逆数か $\mathrm{X}$ 線応力定数 $K(\mathrm{MPa} / \mathrm{deg})$ となる.

RRTでの具体的な方法は，外部応力の付加にはFig. 29に 示す 4 点曲げ試験機を用い，引張，圧縮の両応力を付加した. 応力 $\sigma_{\mathrm{A}}$ はロードセルで荷重 $P$ を求め, 試験片形状から算出 した. Fig. 30に圧縮応力付加時の4点曲げ試験の要領を示す. 試験片上面の付加応力 $\sigma_{\mathrm{A}}$ は以下の式で表せる.

$$
\sigma_{\mathrm{A}}(\mathrm{MPa})=\frac{M}{Z}, M=\frac{P l}{2}, Z=\frac{B h^{2}}{6}
$$

ここで $M$ : 付加モーメント $(\mathrm{Nmm}), Z$ : 断面係数 $\left(\mathrm{mm}^{3}\right)$, $P:$ 付加力 $(\mathrm{N}), B:$ 試験片幅 $(\mathrm{mm}), l:(b-a) / 2(\mathrm{~mm})$, $h$ : 有効板厚 $(\mathrm{mm})$ である。本実験で使用した 4 点曲げ試 験機は $a=110 \mathrm{~mm}, b=60 \mathrm{~mm}$ であり,$l=25 \mathrm{~mm}$ となる。

ここで付加応力 $\sigma_{\mathrm{A}}$ を式（28）で算出する際に問題となる のは，有効板厚hはどんな值を使用すべきかということであ る。使用した試験片は，SUP12試験片（幅 $B=9 \mathrm{~mm} ）$ は幅 方向全面研磨であり，SUP9A試験片では幅 $B=30 \mathrm{~mm}$ の中央 


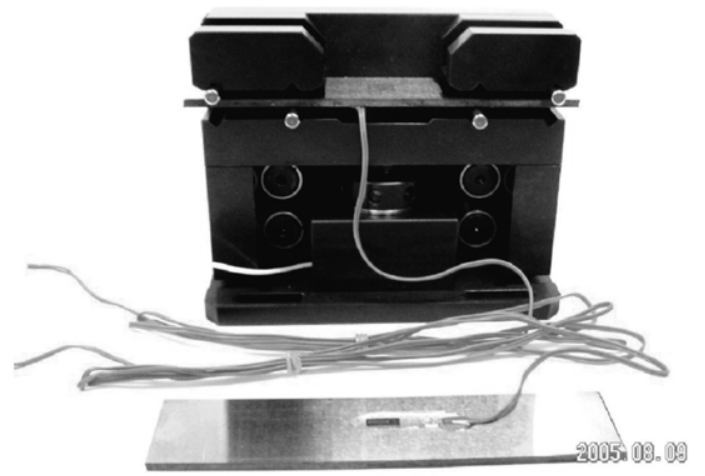

Fig. 29 Four-points bending device with load cell used.

部に $\square 10 \mathrm{~mm}$ の部分電解研磨を行っている。

そこで4点曲げ試験を行ったときの電解研磨領域底部（板 厚 $t=3 \mathrm{~mm}$, 電解研磨深さ $d=0.2 \mathrm{~mm}$ と設定）に発生する応 力の分布を 3 次元弾性有限要素法解析 (ANSYS) で求めた。 その結果, FEM解析による電解研磨領域の中央部の応力值 は, SUP12試験片は有効板厚 $h=t-d$ ( $d$ は電解研磨深さ), SUP9A試験片では $h=t$ とすると, 式（28）で求めた付加応 力值と一致することがわかった。したがってX線測定におけ る試験片の付加応力 $\sigma_{\mathrm{A}}$ は, SUP12試験片では電解研磨後の 板厚を，またSUP9A試験片では電解研磨前の板厚を用いて 式（28）にて算出した。

X線応力定数の測定条件をTable 13に示す. X線照射面積 などの指定しない条件は各RRTの参加委員で設定すること とした。

\section{3 フェライト系ばね鋼のX線応力定数測定結果}

測定結果をFig. 31に示す. SUP9AとSUP12で結果のばら つきに差が見られるのは試験片の形状によるものと考えら れる (SUP12は幅が狭いため)。付加応力 (引張・圧縮）の 違い, SUP9AとSUP12の違いによるX線応力定数值に大きな 差はなかった。よって, 両鋼種のX線応力定数 $K$ の平均值と すべての測定值の $68.3 \%$ 信頼限界を求めると, 次のように なった。

$$
K=-338 \pm 13.1 \mathrm{MPa} / \mathrm{deg}
$$

この值は日本材料学会「X線応力測定法標準」の推奨值 $K=-318 \mathrm{MPa} / \mathrm{deg}$ より $6 \%$ ほど大きな值である。上述したX 線応力定数 $K$ はくまでフェライト系ばね鋼の参考值であ $\eta$, 残留応力の絶対值が必要な場合は, 測定対象のX線応力 定数 Kを実験的に求めることが必要である.

なおX線応力定数測定にあたって，本実験で得られた注 意点を以下に記す。

·試験片作製時の注意点

(1) 寸法は正確に測定する.

（2）電解研磨は加工の影響が充分取れる深さで行う. ・測定時の注意点

（1）電解研磨方法（全面研磨，部分研磨）の相違によ る付加応力の計算上の扱い方.

（2）4点曲げ試験機及び試験片を測定方向に正確に合 わせる。

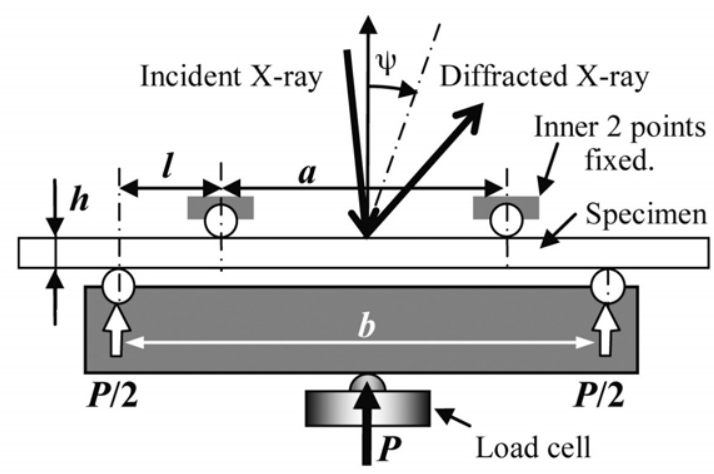

Fig. 30 Layout of four-points bending test for compressive applied stress.

\section{7. 結言}

本研究委員会は発足後，まずばね関連企業でのX線応力 測定の使用実態調査を実施し，その結果を精査して活動方 針をたて，委員会の研究活動を行ってきた。得られた結果 を以下に示す。

1）ショットピーニング処理したばね鋼平板の残留応力測定 をラウンドロビン試験で行った。その結果，各機関とも 任意の測定条件の下で測定されたにも関わらず，平均の $68.3 \%$ 信頼限界值 $(37 \mathrm{MPa})$ は残留応力の平均值（-643 $\mathrm{MPa})$ の\%以下となり，日常の測定条件下の值としては， 実用的に良い精度であった。

2）残留応力測定には， $68.3 \%$ 信頼限界值を基準として最短 時間で目的の基準值を満たす応力測定条件を設定すべき である。一例として，測定誤差 $\Delta \sigma$ をFe粉末と同様な值士 $10 \mathrm{MPa}$ に設定した場合の推奨する条件は以下のとおりと なった。

a) 回折強度曲線のピーク計数值は1000カウント以上.

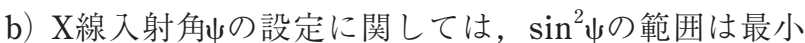
$\sin ^{2} \psi=0$ から最大の $\sin ^{2} \psi$ 值は 0.5 以上. $\psi$ 角点数は 5 点以

上. $\sin ^{2} \psi$ の設定ステップ $\Delta \sin ^{2} \psi$ は等間隔.

3）ショットピーニング処理した丸棒の残留応力測定を行い, X線コリメータ径を測定したい素線径の $20 \%$ 以下にする と，実在する残留応力值との差を $10 \%$ 以下にできること がわかった。さらに測定表面が曲率をもつような形状の 際に，実在する残留応力值を測定するためには，X線コ リメータ径以下の測定領域にマスキングをすることが必 要である。

4) 丸棒にショットピーニング処理を行うと，その条件（特 にファインショットピーニング処理の時）によっては計 数率線図がうねりを有し，軸方向には $\sin ^{2} \psi$ 線図が明瞭な 非直線性を示し，周方向には廿スプリットが現れることが わかった。

5）ショットピーニング処理されたコイルばねや弁ばねのよ うに表面に曲率をもつような試料の残留応力測定を行う 場合，事前に計数率線図が漸減しているかどうか，また $\sin ^{2} \psi$ 線図が直線になっているかどうかを確認した上で, はじめて $\sin ^{2} \psi$ 法による残留応力測定を行う必要がある。 
Table 13 Conditions to measure the X-ray stress constants.

\begin{tabular}{|c|c|c|c|}
\hline \multirow{10}{*}{$\begin{array}{l}\text { Measuring } \\
\text { condition }\end{array}$} & \multicolumn{2}{|c|}{ Characteristic X-ray } & $\mathrm{Cr}-\mathrm{K} \alpha$ (V filter $)$ \\
\hline & \multicolumn{2}{|l|}{ Diffraction $\left(2 \theta_{0}\right)$} & $\alpha \mathrm{Fe} 211 \quad(156.4 \mathrm{deg})$ \\
\hline & \multicolumn{2}{|l|}{ Tube voltage } & $30 \mathrm{kV}$ \\
\hline & Detector: PSPC & MCA & 512 Channels \\
\hline & \multirow{2}{*}{ Detector : SC } & Range & 148deg $\sim 165 \mathrm{deg}$ \\
\hline & & $\Delta 2 \theta$ & $0.05 \mathrm{deg}$ \\
\hline & \multirow{3}{*}{\multicolumn{2}{|c|}{ Measuring method }} & Iso-inclination method \\
\hline & & & Fixed $\psi_{0}$ \\
\hline & & & Non oscillation \\
\hline & \multicolumn{2}{|l|}{ Peak intensity } & $\geq 2000$ counts \\
\hline \multirow{4}{*}{$\begin{array}{c}\text { Analysis for } \\
\text { diffraction profile }\end{array}$} & \multicolumn{2}{|c|}{ Background regression } & (About 20 point at both end) \\
\hline & \multicolumn{2}{|c|}{ Absorption correction } & Done \\
\hline & \multicolumn{2}{|l|}{$\mathrm{K} \alpha_{2}$ separation } & None \\
\hline & \multicolumn{2}{|c|}{ Peak determination } & FWHM middle point method \\
\hline
\end{tabular}

6） $\sin ^{2} \psi$ 線図の評価法として，従来全く行われなかった $\sin ^{2} \psi$ 線図の曲がり度やうねり度などの非直線度の評価法 を提案した。 $\sin ^{2} \psi$ 線図の非直線度を評価するために必要 となるX線入射角点数は，曲がり度のみの検出には少な くとも6点，うねり度を含めて検出するためには7点以上 が必要である。

7）三軸応力状態において深さ方向のせん断応力成分が存在 するあるいは深さ方向に垂直方向の応力勾配が存在する 試料を仮定してシミュレーションで $\sin ^{2} \psi$ 線図を作成した。 作成した $\sin ^{2} \psi$ 線図の曲がり度及びうねり度と $\sin ^{2} \psi$ 法で算 出される応力の関係を検討した。 その結果, 曲がり度及 びうねり度により $\sin ^{2} \psi$ 法が実用的に適用できる限界を提 示できる可能性は十分あることが確認できた.

8）一般的に使用されているフェライト系ばね鋼SUP9Aと SUP12のX線応力定数の測定をラウンドロビン試験した結 果, 両鋼種のX線応力定数Kの平均值と $68.3 \%$ 信頼限界と

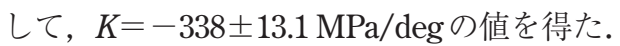

この值は日本材料学会「X線応力測定法標準」のフェライト 系鉄鋼の推奨值 $K=-318 \mathrm{MPa} / \mathrm{deg}$ より $6 \%$ ほど大きな值で あった. 残留応力の絶対值が必要な場合は, 測定対象のX線 応力定数 $K を$ 実験的に求めることが必要である.

\section{謝 辞}

X線応力測定の実態調査アンケート及び 3 回のラウンド ロビン試験にご回答ならびに参加協力をいただいた多くの 関係各位及び委員各位に深謝の意を表します。本来はご協 力いただいた方々のご芳名を記載させていただきたいとこ ろですが，紙面の都合上お許しください。また第1回から第 3回ラウンドロビン試験に際し，材料のご提供及びショット ピーニング加工を行っていただいた本委員会委員中央発條 (株) 三村氏，日本発条(株) 後藤氏，新東工業(株) 小林氏， 辻氏に深く感謝いたします。

最後に諸事大変お世話いただきました日本ばね学会事務 局の方々に深く御礼申し上げます。(委員長 記)

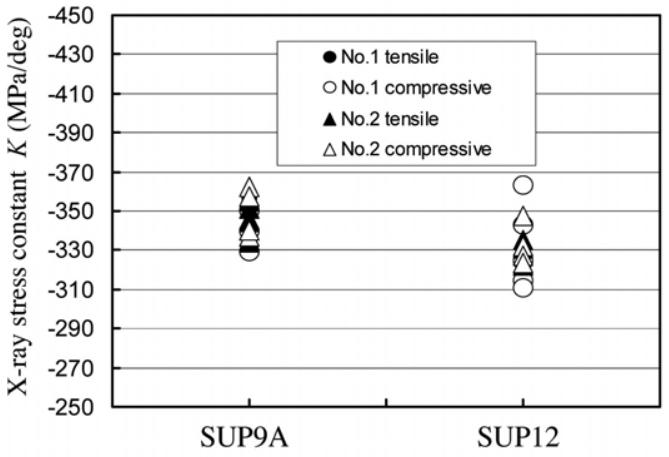

Fig. 31 Results of X-ray stress constant for SUP9A and SUP12.

\section{参考文献}

1）日本材料学会 $X$ 線材料強度部門委員会, “ $X$ 線応力測 定標準一鉄編2002年度版—”, (2002)，日本材料学会.

2) JIS-B2711付属書3 (規定) “残留応力の測定方法”.

3）日本ばね学会 $X$ 線によるばねの残留応力評価法研究 委員会, 日本ばね学会, 2010年度春季 ばね及び復 元力応用講演会講演論文集, $(2010), 35$.

4）小栗泰造, 村田一夫, 水谷勝巳, 材料, 49 (2000), 645 .

5）日本ばね学会 $\mathrm{X}$ 線によるばねの残留応力評価法研究 委員会，日本ばね学会，2011年度春季 ばね及び復 元力応用講演会講演論文集, (2011)，17.

6）吉岡靖夫，佐々木敏彦，倉元眞實，非破壊検査，34 (1985), 52

7) Dolle, H., Hauk, V., HTM, 31 (1976) , 165.

8）日本材料学会編，“改著X線応力測定法”，(1990), P.143，養賢堂.

9）梅本実，ばね技術研究会，2003年度 春期講演会講 演論文集，(2003)，69.

10）間野日出男，近藤覚，松室昭仁，ばね論文集，51 (2006), p17.

11）吉岡靖夫, 大谷眞一, 須山雄二郎, 日本材料学会, 第33回X線材料強度シンポジウム講演論文集, (1997), 1.

12）田中啓介，秋庭義明，河合雅典，伊藤登史政，材 料, 54 (2005), 704 .

13）金子忠夫，三津橋史朗，入戸野修，日本材料学会 学術講演会前刷集，No.38 (1989)， 192.

14）田中啓介，秋庭義明，森下裕介，日本機械学会論 文集A編，71 (2005)，1714。

15）秋庭義明，木村英彦，坂上卓，材料，58（2009）, 575.

16）日本材料学会X線材料強度部門委員会（応力測定と 弾性分科会, 材料, 20 (1971), 1257. 